\title{
A COMPOSITIONAL STUDY OF A SELECTION OF SONG DYNASTY CHINESE CERAMICS FROM THE JAVA SEA SHIPWRECK: RESULTS FROM LA-ICP-MS ANALYSIS
}

\author{
Lisa C. Niziolek \\ Integrative Research Center, The Field Museum, Chicago, Illinois, lniziolek@ fieldmuseum.org \\ Keywords: Maritime trade, Java Sea Shipwreck, Song Dynasty ceramics, compositional analysis, Jingdezhen
}

\begin{abstract}
This paper presents the findings of compositional analysis using a number of Chinese ceramics of different styles from the twelfth-thirteenth-century Java Sea Shipwreck. Specifically discussed are the results of laser ablationinductively coupled plasma-mass spectrometry (LA-ICPMS) analysis conducted at The Field Museum of Natural History in Chicago on a selection of high-fired ceramics from the shipwreck, including qingbai (light whitish-blue glazed), green-glazed, and painted wares. This project was undertaken in order to assess correlations between style and material and to begin to identify potential kiln sites where the pieces were manufactured. By doing so, we can better understand the organization, intensity, and scale of ceramic production in China at the time and how these commodities linked Chinese producers to consumers throughout East and Southeast Asia and the Indian Ocean World.
\end{abstract}

\section{INTRODUCTION}

Based on archaeological research and historical records (e.g., Dreyer 2007; Dunn 1989; Rockhill 1913, 1914, 1915a, b; Zhao 2012 [1911]), it is clear that, during the early to mid-second millennium AD, East and Southeast Asia were part of large, complex maritime trading systems, which included societies living in the South China Sea region as well as the coastal areas along the Indian Ocean and parts of the Middle East. Through these trade networks, China's elite acquired exotic items such as spices, beeswax, aromatic resin, ivory, rhinoceros horn, tortoise shell, coral, pearls, crystal, birds' nests, tropical hardwoods, cotton, and marine delicacies as prestige items. The Southeast Asian political elite procured gold, lead, tin, iron, copper cash, silk, beads, and high-fired ceramics from China, India, the Middle East, and East Africa (Hall 1985, 1999, 2011; Kauz 2010; Miksic, et al. 1994; Reid 1988a, b; Scott 1989; Wade 2009; Wheatley 1959; Wu 1959). During this time, China's ceramic export industry flourished, and high-fired Chinese stoneware and porcelain from this period have been found as far away as South and Southwest Asia and East Africa
(Chaudhuri 1985; Hall and Whitmore 1976; Kauz 2010; Kusimba 1999; Oka, et al. 2009).

In order to promote trade and ensure a stable flow of exotic goods, China's Northern Song dynasty (AD 9601126) instituted a tributary system through which foreign leaders and merchants could gain favored trade status and engage in regular exchange with China (Junker 1999, 2004; Wu 1959). This system thrived for a time; however, trade between China and Southeast Asia became so vigorous that China's own supply of copper cash was depleted (Flecker 2003; Guy 1986). To address this growing deficit, merchants were encouraged to trade ceramics and silk instead, and they found ready markets especially in Southeast Asia and the Middle East.

During the Southern Song dynasty (AD 1126-1279), the Chinese court was forced to relocate south to Hangzhou in Zhejiang province to evade attacks from northern invaders. Consequently, China lost much of its access to the overland routes to the west, and maritime trade ports became increasingly important (Deng 1997; So 2000). During this period, Quanzhou, which was close to Hangzhou, replaced Guangzhou as China's largest port (Figure 1). Also during this period, for the first time ever, private traders from China were allowed and encouraged to engage directly in overseas trade. As a result of this free trade, the tribute system waned and Southeast Asian ports flourished and continued to do so into the Yuan dynasty (AD 1271-1368). Traditionally, scholars have relied largely on historical records and finds from terrestrial archaeological sites to shed light on this history; however, more recently, shipwrecks and other maritime sites have proven to be critical for a more nuanced understanding of trade relationships and commodity production in East and Southeast Asia and the Indian Ocean World (e.g., Descantes, et al. 2002; Dizon 2011; Flecker 2001; Krahl, et al. 2010; Li 2009; Manguin 1993, 2004; Miksic 2011; Miksic and Yap 1992).

\section{THE JAVA SEA SHIPWRECK}

In 1998, the Field Museum of Natural History in Chicago received a donation of more than 7,500 artifacts that had lain 27 meters below the water in the Java Sea for almost eight centuries. Now known as the Java Sea Shipwreck 


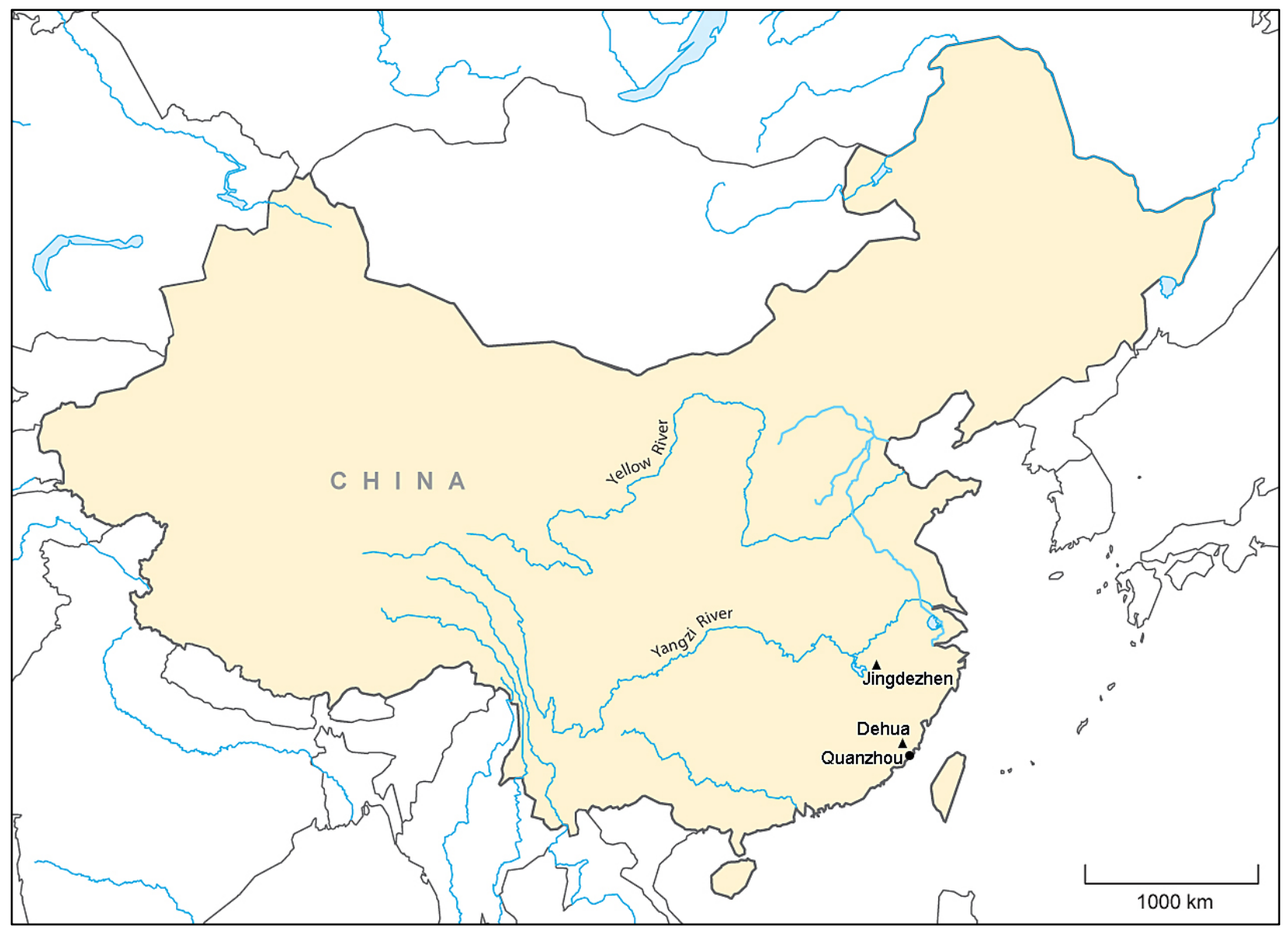

Figure 1: Map of China showing the port of Quanzhou and the kiln sites of Dehua and Jingdezhen

$(J S W)$, this twelfth-thirteenth-century vessel was discovered by fishermen in Indonesian waters between Sumatra and Java in the late 1980s (Flecker 2005-2006) (Figure 2). In 1996, Pacific Sea Resources, a U.S.-based salvage company, worked with Indonesian partners to systematically and legally recover the wreck. Half of the collected material was given to the Indonesian government; the other half was donated to The Field Museum. Some research was undertaken soon after the site was excavated (Bronson 1997; Brown 1997b; Flecker 2003, 2005-2006; Mathers and Flecker 1997); more in-depth analysis began on the wreck material at the Museum in 2012.

The ship, which was likely built in Indonesia, carried an international cargo, including more than 200 tons of iron and 30 tons of ceramics and may have been bound for central Java (Flecker 2005-2006; Mathers and Flecker 1997). Most of the iron would have been in the form of trapezoidal ingots and was likely from China (Bronson 1997), but there are also cauldrons, a small axe head, and scale weights and bars. The majority of ceramics are highfired pieces from China, discussed in more detail below. The collection also includes fine earthenware kendis thought to have been manufactured in Thailand and storage vessels that would have been used to transport organic products, small pieces of pottery, and provisions for the crew (Flecker 2003, 2005-2006; Krahl 2010).
Other items were found onboard in smaller quantities (Mathers and Flecker 1997). These include ivory, aromatic resin, several pieces of glass, and used sharpening stones and scale sets that were likely possessions of the crew and merchants. Tin ingots and portions of copper alloy trays and gongs (likely Chinese), conical and bar ingots of copper, as well as hook-shaped metal pieces also were found. More unique finds made of metal include a stooped, cross-legged figure that was a support for a small table or altar and a figure of a woman riding a mythical sea creature (Flecker 2005-2006; Miksic 1997). Two finials also were recovered, similar to those found in Java that would have been mounted atop wooden staffs carried by mendicants (Singapore National Heritage Board and National Museum (Singapore) 1995:142-143).

Evidence of the mass production of ceramics abounds in China in the form of massive kiln complexes such as those found at Jingdezhen, Changsha, and Foshan (Ho 1994b; Hughes-Stanton and Kerr 2000; Mino 1992; Mino and Wilson 1973; Phillips 1956; Scott 1993; Wood 2011; Ye 1994). Terrestrial archaeological sites throughout Southeast Asia bear witness to frequent trade with China and, in the Philippines, for instance, large quantities of Chinese trade ceramics, and later Vietnamese and Thai pottery, are the result of large-scale foreign trade (Fox and Legaspi 1977; Junker 1999; Nishimura 1992; 


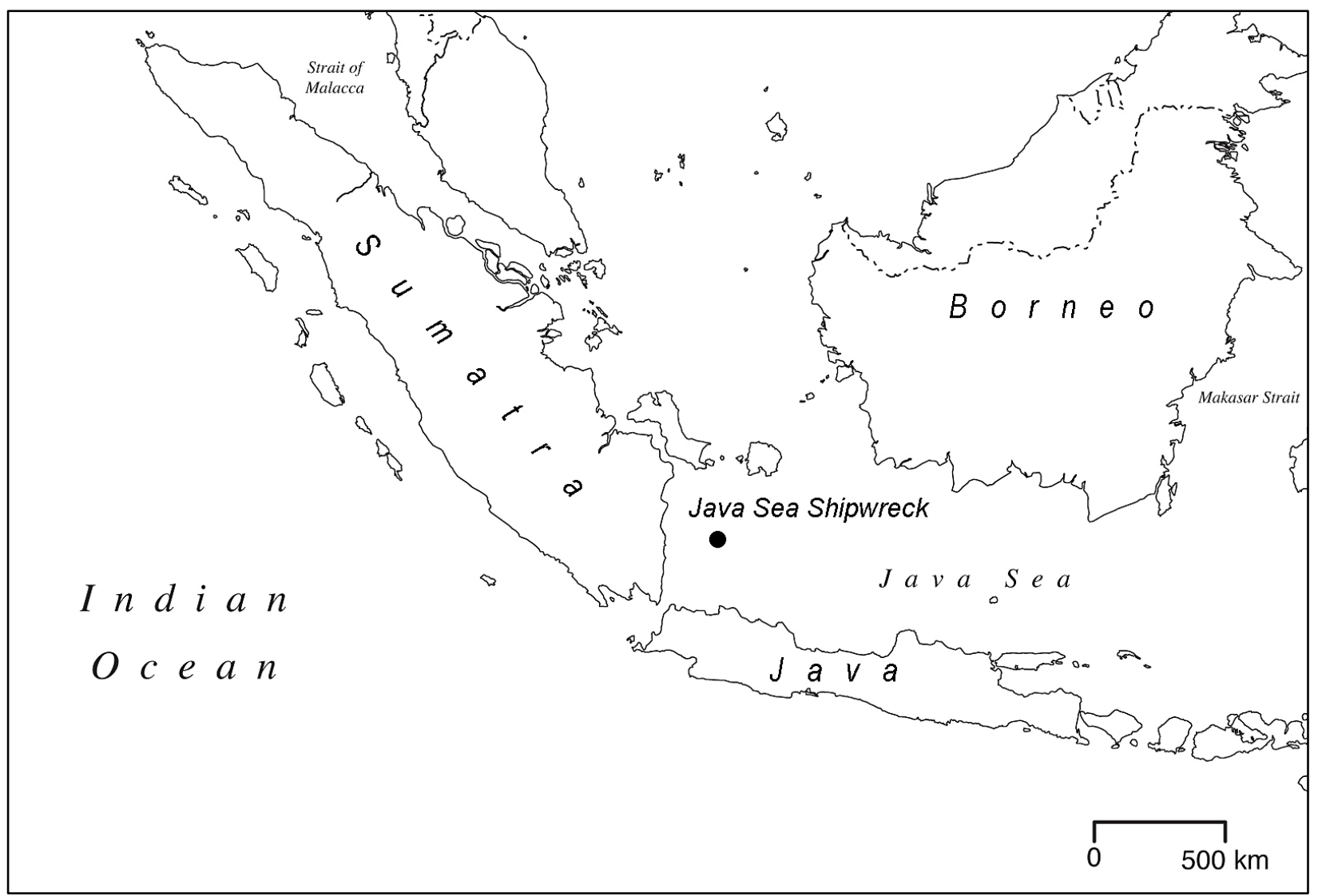

Figure 2: Location of the Java Sea Shipwreck

Tenazas and Hutterer 1968; Wong 2010). Shipwrecks carrying cargos of mostly Chinese export ceramics-but some transporting items from Southeast Asia and elsewhere to China-also indicate vigorous overseas trade (Diem 2004; Dupoizat 1995; Flecker 2001; Grave, et al. 2005; Krahl, et al. 2010; Li 2009; Wade 2003).

Most of the high-fired ceramics from the $J S W$ have been identified as Song dynasty Chinese wares and include fine bowls, dishes, vases, bottles, boxes, and jars ranging from small covered boxes with light blue glaze to celadon bowls incised with floral motifs to graceful pitchers with intricate black and white designs that were once covered with bright green glaze. While it is certain that the majority of these ceramics originated in China and it has been hypothesized at which kiln areas certain ware types were manufactured, provenance research based on style and form is complicated by the fact that certain ceramic types were made at multiple production centers (Dupoizat 1995; Ho 1994b; Ye 1994). For example, it is suspected that finely made qingbai ceramics were made at the famous Jingdezhen kilns in Jiangxi province whereas other ceramics copying the qingbai style were made at Dehua or Anxi in Fujian province (Brown 1997a; Dupoizat 1995; Flecker 2003, 2005, 2005-2006; Guy 1986; Hughes-Stanton and Kerr 2000). Geochemical analysis, then, can aid in the identification and confirmation of the locales (or kiln complexes) where this diverse cargo was produced.

\section{LA-ICP-MS ANALYSIS OF HIGH-FIRED CERAMICS FROM THE JAVA SEA SHIPWRECK}

Compositional analysis is now frequently employed in archaeology to address questions of origin, production, and distribution, especially with regards to pottery, and can be used to identify ceramic pieces in the $J S W$ collection that were made at the same production areas. In turn, this knowledge can be used to reconstruct the organization of production and develop hypotheses regarding exchange networks in East and Southeast Asia during the early to mid-second millennium AD. These regional exchange networks, then, fed into larger transregional systems that spanned half the globe and included diverse political, economic, and social organizations.

The analytical method used most frequently to examine the elemental composition of Chinese ceramics has been X-ray fluorescence (XRF) (e.g., Bao, et al. 2006; Leung and Luo 2000; Yap 1991; Yu and Miao 1996, 1997, 1998; Zhang, et al. 2009; Zhu, et al. 2011). More recently, though, researchers (e.g., Oka, et al. 2009; Zhu, et al. 2012) have applied LA-ICP-MS to geochemical studies of Chinese ceramics with great success, and this is one of the best methods for determining the elemental makeup of ceramic materials. LA-ICP-MS is a seminondestructive method that is capable of determining the concentrations of 50-60 elements, many of which are trace elements critical to distinguishing chemical groups represented in ceramic assemblages from China ( $\mathrm{Li}$, et al. 
2005; Li, et al. 2003; Li, et al. 2006; Zhu, et al. 2010) and elsewhere. The detection limits of LA-ICP-MS also are excellent, reading elements present in the parts per million (Dussubieux, et al. 2007). Its rapid analytical time, low cost, high sample throughput, semi-nondestructive nature (marks left behind are barely visible to the naked eye), and the limited chance of contamination during preparation procedures (done in situ), makes LA-ICP-MS attractive to archaeologists and other researchers (Speakman, et al. 2007). Because it can target specific materials in the sample, such as glaze, slip, temper, or clay, through spot or line analysis, it is a good option for ceramic compositional studies.

\section{Sample and Methods}

The current project, undertaken using LA-ICP-MS at the Elemental Analysis Facility (EAF) at The Field Museum, had two main goals: (1) to determine if ceramics of different styles in the $J S W$ collection could be differentiated chemically and (2) whether or not more than one production area was represented by $J S W$ ceramics made in the qingbai tradition. The pastes, or bodies, of 58 samples were analyzed, while the glazes of 31 samples were tested (Table 1). The majority of these pieces were suspected to be authentic qingbai ceramics made at Jingdezhen in Jiangxi province (Figure 1); however, a number of pieces in the $J S W$ collection, while resembling qingbai, were hypothesized to have been imitations of it based on visual assessment of glazes (clearer, glassier, and more evenly applied in qingbai pieces) and pastes (finer and purer white in color). The pastes of the qingbai and qingbaistyle ceramics are fine or fine-medium in texture and sugary-white or cream. The glazes include translucent aqua, light blue-aqua, and milky blue (Figures 3 and 4). Several green-glazed bowls (Figure 5) also were sampled as well as Cizhou-style pieces (referred to as "painted ware") (Figure 6). All of the green-glazed bowls sampled have incised and combed cloud designs. Their pastes range from lavender-gray to cream to white and their glazes from light olive green to pale gray-green to light blue. The pastes of the painted ware vessels are all fine textured but range in color from white to cream to gray. All of them have designs executed in underglaze black covered by a lead-based, bright green glaze, which is badly weathered in many cases. Appendix 1 provides basic descriptive information for each of the samples.

Table 1: Frequencies of ceramic paste and glaze samples by style analyzed using LA-ICP-MS.

\begin{tabular}{lllll}
\hline & Paste & \multicolumn{3}{c}{ Glaze } \\
\hline Ware & Frequency & $\%$ & Frequency & $\%$ \\
\hline Qingbai & 25 & $43 \%$ & 11 & $35 \%$ \\
Qingbai-style & 8 & $14 \%$ & 17 & $55 \%$ \\
Green-glazed & 12 & $21 \%$ & 3 & $10 \%$ \\
Painted & 13 & $22 \%$ & 0 & $0 \%$ \\
Total & $\mathbf{5 8}$ & $100 \%$ & $\mathbf{3 1}$ & $100 \%$ \\
\hline
\end{tabular}

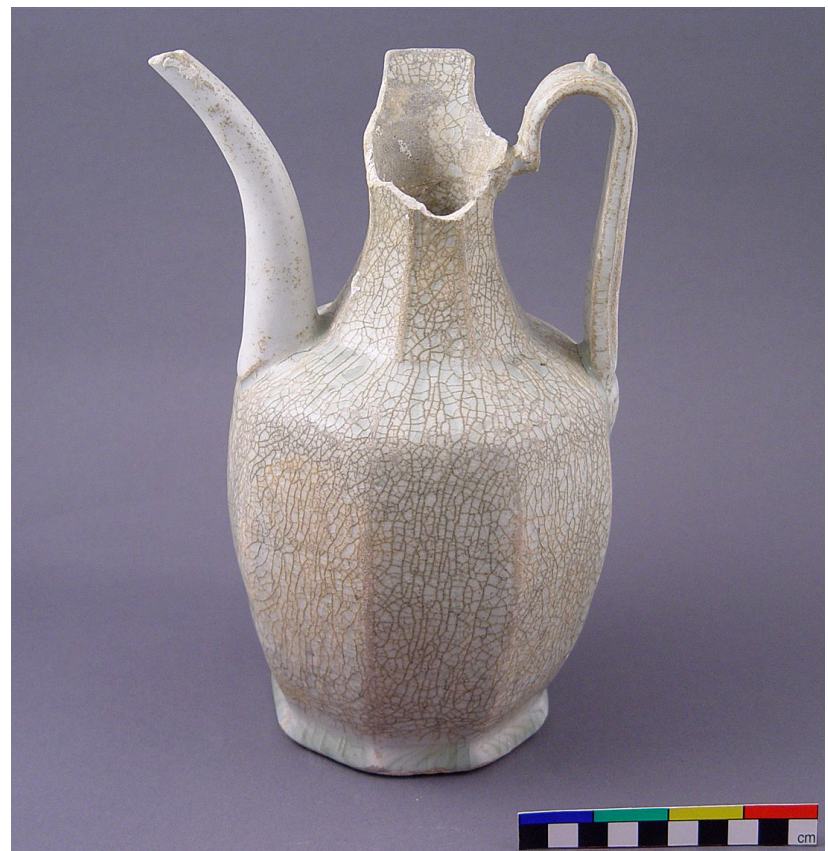

Figure 3: Qingbai ewer from the Java Sea Shipwreck (Photo (C) The Field Museum, Catalog \#350385)

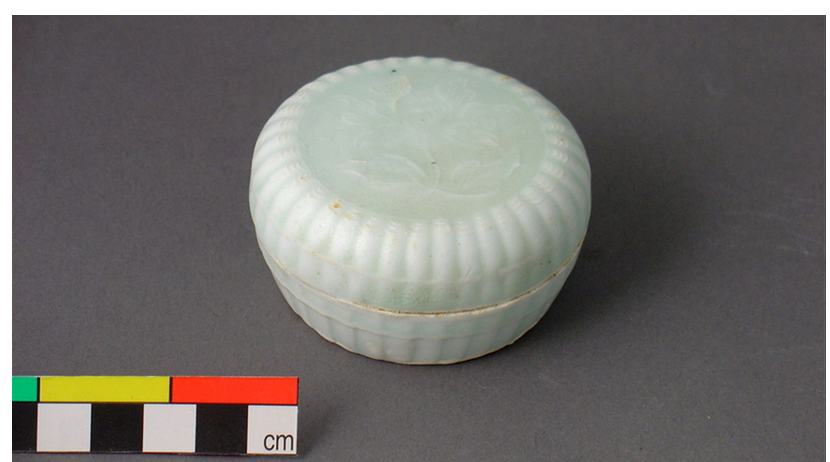

Figure 4: Qingbai-style covered box from the Java Sea Shipwreck (Photo (C) The Field Museum, Catalog \#344284)

The EAF houses an Analytik Jena quadrupole ICP-MS with a New Wave UP213 laser that uses a $213 \mathrm{~nm}$ wavelength laser. The ablation chamber is six centimeters in diameter and five centimeters deep and can hold several small samples at once. Additional technical details can be found in Dussubieux, et al. (2007). The spectrometer was set to measure 58 elemental isotopes for each sample: ${ }^{7} \mathrm{Li}$, ${ }^{9} \mathrm{Be},{ }^{11} \mathrm{~B},{ }^{23} \mathrm{Na},{ }^{24} \mathrm{Mg},{ }^{27} \mathrm{Al},{ }^{29} \mathrm{Si},{ }^{31} \mathrm{P},{ }^{35} \mathrm{Cl},{ }^{39} \mathrm{~K},{ }^{44} \mathrm{Ca},{ }^{45} \mathrm{Sc}$, ${ }^{49} \mathrm{Ti},{ }^{51} \mathrm{~V},{ }^{53} \mathrm{Cr},{ }^{55} \mathrm{Mn},{ }^{57} \mathrm{Fe},{ }^{59} \mathrm{Co},{ }^{60} \mathrm{Ni},{ }^{65} \mathrm{Cu},{ }^{66} \mathrm{Zn},{ }^{75} \mathrm{As},{ }^{78} \mathrm{Se}$, ${ }^{85} \mathrm{Rb},{ }^{88} \mathrm{Sr},{ }^{89} \mathrm{Y},{ }^{90} \mathrm{Zr},{ }^{93} \mathrm{Nb},{ }^{98} \mathrm{Mo},{ }^{107} \mathrm{Ag},{ }^{111} \mathrm{Cd},{ }^{115} \mathrm{In},{ }^{118} \mathrm{Sn}$, ${ }^{121} \mathrm{Sb},{ }^{133} \mathrm{Cs},{ }^{137} \mathrm{Ba},{ }^{139} \mathrm{La},{ }^{140} \mathrm{Ce},{ }^{141} \mathrm{Pr},{ }^{146} \mathrm{Nd},{ }^{147} \mathrm{Sm},{ }^{153} \mathrm{Eu}$, ${ }^{157} \mathrm{Gd},{ }^{159} \mathrm{~Tb},{ }^{163} \mathrm{Dy},{ }^{165} \mathrm{Ho},{ }^{166} \mathrm{Er},{ }^{169} \mathrm{Tm},{ }^{172} \mathrm{Yb},{ }^{175} \mathrm{Lu},{ }^{178} \mathrm{Hf}$, ${ }^{181} \mathrm{Ta},{ }^{182} \mathrm{~W},{ }^{197} \mathrm{Au},{ }^{206,207,}{ }^{208} \mathrm{~Pb},{ }^{209} \mathrm{Bi},{ }^{232} \mathrm{Th}$, and ${ }^{238} \mathrm{U}$. The laser was set to operate at 70 percent energy $(0.2 \mathrm{~mJ})$ with a pulse frequency of $15 \mathrm{~Hz}$.

For the paste analysis, a total of 10 locations on each sample were chosen for a $100-\mu \mathrm{m}$ spot ablation (with a brief pre-ablation to remove surface contamination). Standard reference materials (SRM) with known ranges of elemental concentrations - n610 (glass) and n679 (Brick Clay)-were run every five to 10 samples to correct for 
instrument drift over time (Speakman, et al. 2007). Ohio Red Clay served as a measure of quality control. For the glaze analysis, procedures outlined in Oka, et al. (2009) were followed. Following a pre-ablation pass, a line 55 $\mu \mathrm{m}$ wide by $500 \mu \mathrm{m}$ long by five $\mu \mathrm{m}$ deep was used to ablate the material of interest (e.g., glaze). A total of four readings were taken for each sample and glass standards n612, n610, Corning B, and Corning D were used. (In cases where high lead content was suspected, as with the painted ware glazes, SRM Corning $\mathrm{C}$ was included as well.) After analysis, data was processed per EAF protocols using Microsoft Excel. Statistical analysis was performed on the dataset using Microsoft Excel and GAUSS, an Aptech Systems, Inc. program with routines developed by Hector Neff and Michael Glascock at the University of Missouri Research Reactor Center (MURR).

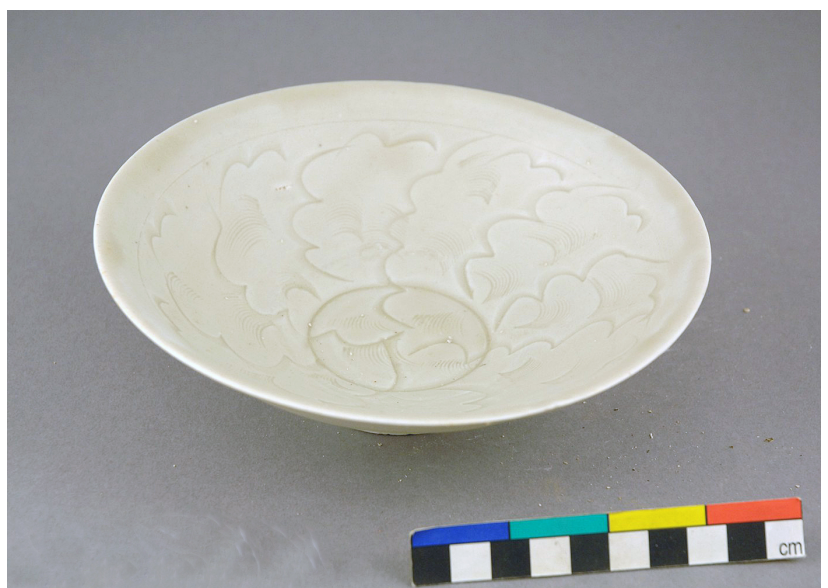

Figure 5: Green-glazed bowl from the Java Sea Shipwreck (Photo (C) The Field Museum, Catalog \#349352)

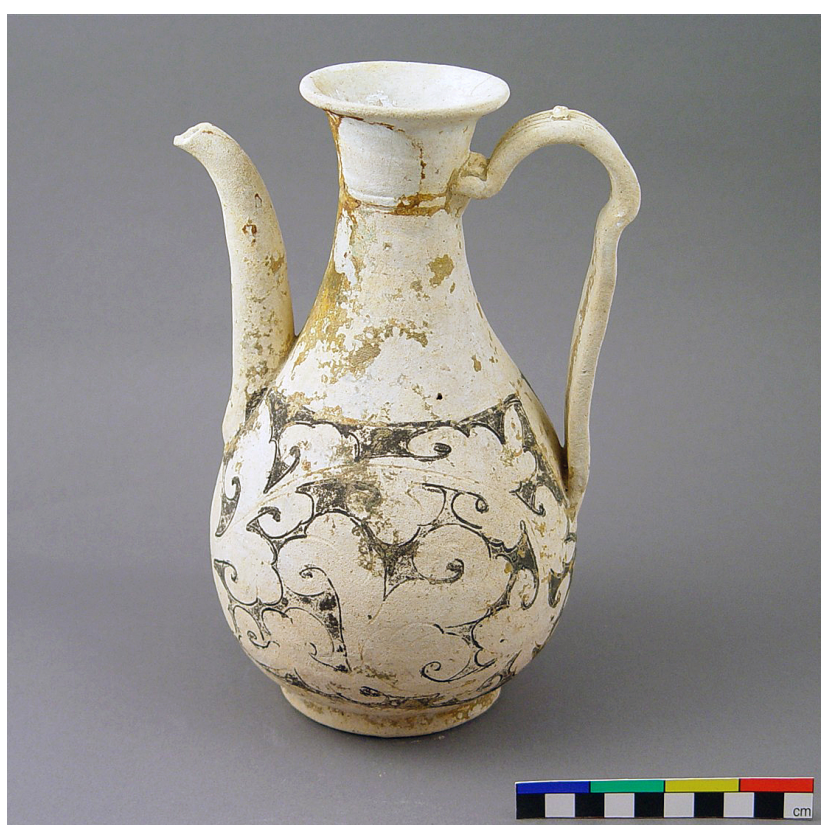

Figure 6: Painted (Cizhou-style) ewer from the Java Sea Shipwreck (Photo (C) The Field Museum, Catalog \#350392)

\section{Results and Discussion of the Paste Analysis}

Of the original 58 elements measured by LA-ICP-MS, 45 were retained for statistical analysis: $\mathrm{Li}, \mathrm{Be}, \mathrm{B}, \mathrm{Na}, \mathrm{Mg}$, $\mathrm{Al}, \mathrm{Si}, \mathrm{K}, \mathrm{Sc}, \mathrm{Ti}, \mathrm{V}, \mathrm{Cr}, \mathrm{Mn}, \mathrm{Fe}, \mathrm{Ni}, \mathrm{Cu}, \mathrm{Zn}, \mathrm{Rb}, \mathrm{Sr}, \mathrm{Y}, \mathrm{Zr}$, $\mathrm{Nb}, \mathrm{Sn}, \mathrm{Sb}, \mathrm{Cs}, \mathrm{Ba}, \mathrm{La}, \mathrm{Ce}, \mathrm{Pr}, \mathrm{Nd}, \mathrm{Sm}, \mathrm{Eu}, \mathrm{Gd}, \mathrm{Tb}, \mathrm{Dy}$, Ho, Er, Tm, Yb, Lu, Hf, Ta, Bi, Th, and U. Because of questionable readings on the rare earth elements for JSW164, this sample was removed from further analysis. This piece, from a painted ewer, was badly weathered, which may account for anomalous elemental concentrations. All results were converted from parts-per-million to $\log$ base-10 values and were processed using wellestablished statistical routines for ceramic compositional data (Baxter 2001; Dussubieux, et al. 2007; Eerkens, et al. 2002; Glascock, et al. 2004; Kennett, et al. 2004; Neff 1994; Niziolek 2013a, b).

The first step in statistical analysis was to identify potential outliers to the dataset. This was done by inspecting an elemental biplot of $\mathrm{Si}$ and $\mathrm{Al}$ and a dendrogram using hierarchical cluster analysis of logged elemental values and calculating Mahalanobis distance probabilities of group membership. JSW 125 had a low probability of group membership (0.005) and was an outlier on the dendrogram and biplot, so it was removed from subsequent statistical analysis. Compared to other samples, it has higher concentrations of $\mathrm{Ca}$ and $\mathrm{Sr}$ and lower concentrations of Fe. Other samples removed based on low Mahalanobis distance probabilities (less than one percent) include JSW158, JSW160, JSW170, and JSW193 (see Table 2). JSW158 has higher concentrations of Mg; JSW 160 has lower concentrations of Na and Ba; JSW170 has higher concentrations of Ti; and JSW193 has lower concentrations of $\mathrm{Ba}$. The remaining samples all have Mahalanobis distance membership probabilities greater than one percent and form the core paste dataset.

Next, principal components analysis (PCA) was performed on the correlation matrix in order to compress the 45 elemental variables into a more manageable number. Because many statistical procedures require a larger number of samples than variables, PCA enables this assumption to be met while retaining a high expression of variability. The first five principal components (PCs) all have eigenvalues greater than one and account for almost 90 percent of the elemental variance in the dataset. Mahalanobis distance probabilities were again calculated using the PC values and confirmed that none of the core group samples have a probability of less than one percent.

After PCA, samples were split into four groups based on style: painted, green-glazed, qingbai-style, and qingbai. Mahalanobis distance probabilities using PCs 1-5 were calculated for these four groups to see if any sample had a higher probability of being in a group other than its suspected style group. Hierarchical cluster analysis also was run on the PC values. Based on the results of these techniques and inspection of PC biplots, it was decided to combine the green-glazed and qingbai-style samples into one group. Table 3 shows that many of the samples in these two groups have relatively high probabilities of group membership in both groups based on Mahalanobis 
distance calculations using the first four principal components. Furthermore, in some instances, different forms and styles may have been manufactured at the same production site (Qin Dashu, personal communication, October 24, 2015). Additional calculations of Mahalanobis distance probabilities using the PC values of the different style groups suggested a number of samples should be removed (JSW121, JSW197, JSW134, and JSW122). After these samples were removed, no additional samples had Mahalanobis distance membership probabilities of less than one percent in their respective style groups (Table 4).

Table 2: Group membership probabilities of paste samples based on Mahalanobis distance calculations using logged elemental values of the 45 elements retained for statistical analysis. Samples that are in bold and italicized have a less than one percent probability of group membership.

\begin{tabular}{llll}
\hline Sample ID & \% Probability & Sample ID & $\%$ Probability \\
\hline JSW121 & 5.708 & JSW170 & $\mathbf{0 . 4 5 9}$ \\
JSW122 & 1.516 & JSW171 & 20.301 \\
JSW123 & 37.507 & JSW173 & 27.660 \\
JSW124 & 8.065 & JSW174 & 65.254 \\
JSW125 & $\mathbf{0 . 0 0 3}$ & JSW188 & 31.356 \\
JSW126 & 86.826 & JSW189 & 47.996 \\
JSW127 & 24.426 & JSW190 & 82.849 \\
JSW129 & 87.804 & JSW191 & 91.390 \\
JSW131 & 7.684 & JSW192 & 99.943 \\
JSW133 & 89.216 & JSW193 & $\mathbf{0 . 7 3 1}$ \\
JSW134 & 1.143 & JSW194 & 91.800 \\
JSW135 & 29.177 & JSW195 & 59.974 \\
JSW136 & 37.783 & JSW196 & 85.939 \\
JSW137 & 66.127 & JSW197 & 12.451 \\
JSW138 & 2.499 & JSW198 & 99.031 \\
JSW139 & 32.546 & JSW199 & 35.241 \\
JSW151 & 36.278 & JSW200 & 79.491 \\
JSW152 & 51.728 & JSW201 & 4.834 \\
JSW153 & 93.199 & JSW202 & 3.549 \\
JSW154 & 41.121 & JSW203 & 89.969 \\
JSW156 & 42.472 & JSW204 & 99.855 \\
JSW157 & 68.157 & JSW205 & 13.722 \\
JSW158 & $\mathbf{0 . 1 2 8}$ & JSW206 & 4.663 \\
JSW159 & 91.514 & JSW207 & 17.108 \\
JSW160 & $\mathbf{0 . 0 0 4}$ & JSW208 & 98.193 \\
JSW161 & 59.807 & JSW900 & 10.704 \\
JSW163 & 38.245 & JSW902 & 96.310 \\
JSW165 & 57.144 & JSW901 & 98.660 \\
JSW168 & 95.524 & 98.788 \\
JSW169 & 63.774 & & \\
\hline
\end{tabular}

LA-ICP-MS analysis of the ceramic pastes indicates that there are at least three chemical groups, which correspond closely with style (Figure 7). Table 5 lists the average elemental concentrations of the different chemical groups. Group 1 is made up of painted ware samples and can be split into two subgroups based on paste color and form [bowls with white paste (Figure 8) and ewers with gray paste (Figure 9)]. This group is characterized by higher concentrations of $\mathrm{Ti}, \mathrm{Mg}, \mathrm{Sc}, \mathrm{V}, \mathrm{Cr}, \mathrm{Ni}, \mathrm{Cu}, \mathrm{Zr}, \mathrm{Sn}$, $\mathrm{Hf}$, Ta, and Bi. Group 2 is comprised of green-glazed and qingbai-style pieces and has higher amounts of $\mathrm{Y}$ and $\mathrm{Th}$ and lower concentrations of $\mathrm{Rb}$. Group 3 is significantly different chemically from Groups 2 and 3 and has higher concentrations of $\mathrm{Ca}, \mathrm{Na}, \mathrm{Li}, \mathrm{Be}, \mathrm{B}, \mathrm{Mn}, \mathrm{Sb}, \mathrm{Cs}$, and $\mathrm{U}$ and lower quantities of the rare earth elements. After these main chemical groups were established, samples that had been taken out throughout the analysis were reprojected back into these main groups. Only JSW158 could be convincingly reassigned (to Group 1, painted ware). The other samples all had very low probabilities of belonging to the established compositional groups. The reasons for this are uncertain since these samples do not appear to be different in terms of style or paste appearance.

Table 3: Group membership probabilities of green-glazed and qingbai-style paste samples based on Mahalanobis distance calculations using the first four principal components values.

\begin{tabular}{lllll}
\hline \multicolumn{5}{c}{ Ware Type } \\
Sample ID & Painted & $\begin{array}{l}\text { Green- } \\
\text { glazed }\end{array}$ & $\begin{array}{l}\text { Qingbai- } \\
\text { style }\end{array}$ & Qingbai \\
\hline Green-glazed & group & & & \\
JSW135 & 0.050 & 1.801 & 20.946 & 0.000 \\
JSW154 & 0.002 & 10.327 & 55.457 & 0.000 \\
JSW196 & 0.010 & 96.942 & 93.973 & 0.000 \\
JSW198 & 0.005 & 88.104 & 55.398 & 0.000 \\
JSW199 & 0.034 & 82.774 & 90.986 & 0.000 \\
JSW200 & 0.050 & 43.817 & 74.332 & 0.000 \\
JSW202 & 0.003 & 4.299 & 73.406 & 0.000 \\
JSW203 & 0.004 & 92.016 & 88.029 & 0.000 \\
JSW204 & 0.006 & 91.772 & 94.756 & 0.000 \\
JSW205 & 0.006 & 10.889 & 77.099 & 0.000 \\
JSW206 & 0.059 & 46.555 & 64.507 & 0.000 \\
JSW208 & 0.071 & 62.826 & 86.690 & 0.000 \\
Qingbai-style & group & & & \\
JSW122 & 1.954 & 0.000 & 59.416 & 0.000 \\
JSW123 & 0.016 & 70.155 & 94.146 & 0.000 \\
JSW124 & 0.063 & 2.550 & 26.875 & 0.000 \\
JSW134 & 1.465 & 0.000 & 56.854 & 0.000 \\
JSW188 & 0.011 & 81.234 & 28.851 & 0.000 \\
JSW207 & 0.005 & 59.403 & 56.656 & 0.000 \\
\hline
\end{tabular}

Based on the elemental concentrations of some of the major, minor, and trace elements it is possible to offer some preliminary production area assignments for some of the chemical groups. In 2000, Leung and Luo published a paper in which they present criteria that are helpful for distinguishing not only production regions (i.e., northern China vs. southern China) but also different kiln sites in the south. Specifically, they compare porcelain samples from Hebei in the north to samples from Jingdezhen (Jiangxi province) and Dehua (Fujian province) in the south (Figure 1), the two main kiln areas known to have produced ceramics in the qingbai tradition. Kilns in both of these areas produced ceramics that are visually similar to those found in the $J S W$ cargo and, because data is available for them, provide a good starting point for comparisons - although it must be acknowledged that this comparison is limited in scope, larger scale and more indepth analysis is planned for the future. Pieces made at Jingdezhen or Dehua have $\mathrm{Zr} / \mathrm{Rb}$ ratios less than 1.29 
while those from Hebei have $\mathrm{Zr} / \mathrm{Rb}$ ratios higher than 1.29. For the $J S W$ samples used in this project, almost all of the samples have $\mathrm{Zr} / \mathrm{Rb}$ ratios significantly less than 1.29 , with the exception of some of the samples from Subgroup 1B (JSW129, JSW169, JSW174, JSW901, and JSW904) (Table 6). Another criterion Leung and Luo (2000) look at is the value of $0.79(\mathrm{Rb} / \mathrm{Y}+\mathrm{Zr} / \mathrm{Y})$. If this value is greater six, Jingdezhen may be the production site; if it is less than six, then Dehua might be the source. (Yap, et al. 1987 also identify Rb, Zr, and Y among some of the main elements important for discerning ceramic production sites in China.) Based on this criterion, the $J S W$ samples in Group 2 appear to have been made at Dehua whereas those in Group 3 and Subgroup 1A were possibly made at the famous kilns of Jingdezhen (Table $6)$.

Table 4: Mahalanobis distance probabilities of group membership for the three main paste groups based on style

\begin{tabular}{|c|c|c|c|c|}
\hline Sample & $\begin{array}{l}\text { Group } 1 \\
\text { (1A \& 1B) }\end{array}$ & Group 2 & Group 3 & Best Group \\
\hline JSW129 & 45.65 & 0.00 & 0.00 & Painted ware (Group 1) \\
\hline JSW159 & 68.12 & 0.00 & 0.00 & Painted ware (Group 1) \\
\hline JSW165 & 11.32 & 0.00 & 0.00 & Painted ware (Group 1) \\
\hline JSW169 & 50.92 & 0.00 & 0.00 & Painted ware (Group 1) \\
\hline JSW171 & 29.48 & 0.00 & 0.00 & Painted ware (Group 1) \\
\hline JSW173 & 23.17 & 0.00 & 0.00 & Painted ware (Group 1) \\
\hline JSW174 & 40.92 & 0.01 & 0.00 & Painted ware (Group 1) \\
\hline JSW901 & 95.40 & 0.00 & 0.00 & Painted ware (Group 1) \\
\hline JSW904 & 84.64 & 0.00 & 0.00 & Painted ware (Group 1) \\
\hline JSW123 & 0.01 & 70.25 & 0.00 & Green-glazed/Qingbai-style (Group 2) \\
\hline JSW154 & 0.00 & 20.56 & 0.00 & Green-glazed/Qingbai-style (Group 2) \\
\hline JSW188 & 0.01 & 50.22 & 0.00 & Green-glazed/Qingbai-style (Group 2) \\
\hline JSW196 & 0.01 & 86.78 & 0.00 & Green-glazed/Qingbai-style (Group 2) \\
\hline JSW198 & 0.01 & 48.07 & 0.00 & Green-glazed/Qingbai-style (Group 2) \\
\hline JSW199 & 0.01 & 92.41 & 0.00 & Green-glazed/Qingbai-style (Group 2) \\
\hline JSW200 & 0.01 & 27.21 & 0.00 & Green-glazed/Qingbai-style (Group 2) \\
\hline JSW202 & 0.00 & 4.14 & 0.00 & Green-glazed/Qingbai-style (Group 2) \\
\hline JSW203 & 0.01 & 79.22 & 0.00 & Green-glazed/Qingbai-style (Group 2) \\
\hline JSW204 & 0.01 & 97.07 & 0.00 & Green-glazed/Qingbai-style (Group 2) \\
\hline JSW205 & 0.00 & 3.11 & 0.00 & Green-glazed/Qingbai-style (Group 2) \\
\hline JSW206 & 0.02 & 52.32 & 0.00 & Green-glazed/Qingbai-style (Group 2) \\
\hline JSW207 & 0.01 & 11.44 & 0.00 & Green-glazed/Qingbai-style (Group 2) \\
\hline JSW208 & 0.02 & 71.48 & 0.00 & Green-glazed/Qingbai-style (Group 2) \\
\hline JSW126 & 0.00 & 0.00 & 82.05 & Qingbai (Group 3) \\
\hline JSW127 & 0.00 & 0.00 & 8.04 & Qingbai (Group 3) \\
\hline JSW131 & 0.01 & 0.00 & 63.90 & Qingbai (Group 3) \\
\hline JSW133 & 0.01 & 0.00 & 44.30 & Qingbai (Group 3) \\
\hline JSW136 & 0.01 & 0.00 & 77.94 & Qingbai (Group 3) \\
\hline JSW137 & 0.01 & 0.00 & 45.77 & Qingbai (Group 3) \\
\hline JSW138 & 0.01 & 0.00 & 26.24 & Qingbai (Group 3) \\
\hline JSW139 & 0.01 & 0.00 & 22.90 & Qingbai (Group 3) \\
\hline JSW151 & 0.00 & 0.00 & 53.34 & Qingbai (Group 3) \\
\hline JSW152 & 0.00 & 0.00 & 42.27 & Qingbai (Group 3) \\
\hline JSW153 & 0.00 & 0.00 & 68.59 & Qingbai (Group 3) \\
\hline JSW156 & 0.00 & 0.00 & 42.85 & Qingbai (Group 3) \\
\hline JSW157 & 0.00 & 0.00 & 71.71 & Qingbai (Group 3) \\
\hline JSW161 & 0.00 & 0.00 & 95.63 & Qingbai (Group 3) \\
\hline JSW163 & 0.00 & 0.00 & 16.16 & Qingbai (Group 3) \\
\hline JSW168 & 0.00 & 0.00 & 7.25 & Qingbai (Group 3) \\
\hline JSW189 & 0.00 & 0.00 & 90.69 & Qingbai (Group 3) \\
\hline JSW190 & 0.00 & 0.00 & 26.79 & Qingbai (Group 3) \\
\hline JSW191 & 0.00 & 0.00 & 83.97 & Qingbai (Group 3) \\
\hline JSW192 & 0.00 & 0.00 & 39.91 & Qingbai (Group 3) \\
\hline JSW194 & 0.00 & 0.00 & 74.09 & Qingbai (Group 3) \\
\hline JSW195 & 0.00 & 0.00 & 45.84 & Qingbai (Group 3) \\
\hline JSW201 & 0.01 & 0.00 & 20.32 & Qingbai (Group 3) \\
\hline JSW900 & 0.00 & 0.00 & 8.37 & Qingbai (Group 3) \\
\hline JSW902 & 0.01 & 0.00 & 57.21 & Qingbai (Group 3) \\
\hline
\end{tabular}




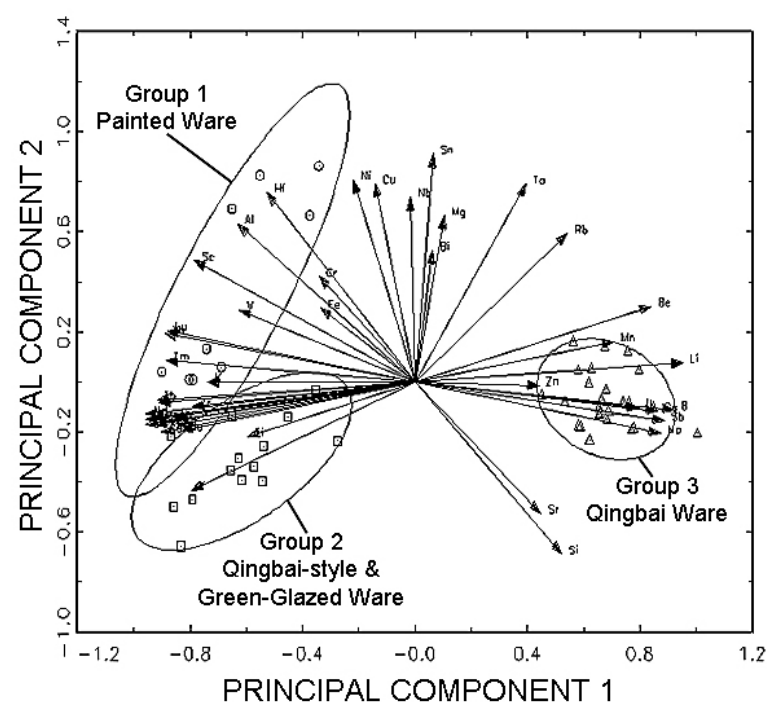

Figure 7: $R$-Q mode biplot of principal components 1 and 2 based on paste compositions. Ellipses represent 90 percent confidence intervals. Circles represent painted samples (Group 1), squares qingbai-style and green-glazed samples (Group 2), and triangles qingbai samples (Group 3).

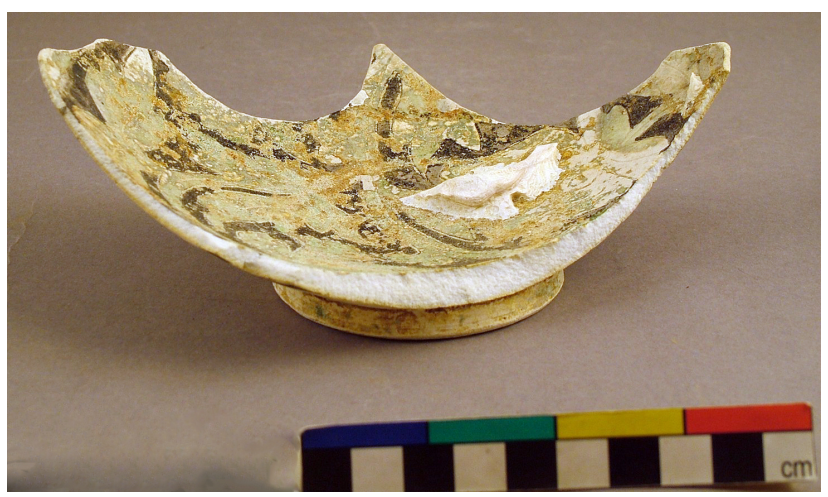

Figure 8: Painted ware bowl from the Java Sea Shipwreck (Photo (C) The Field Museum, Catalog \#350229)

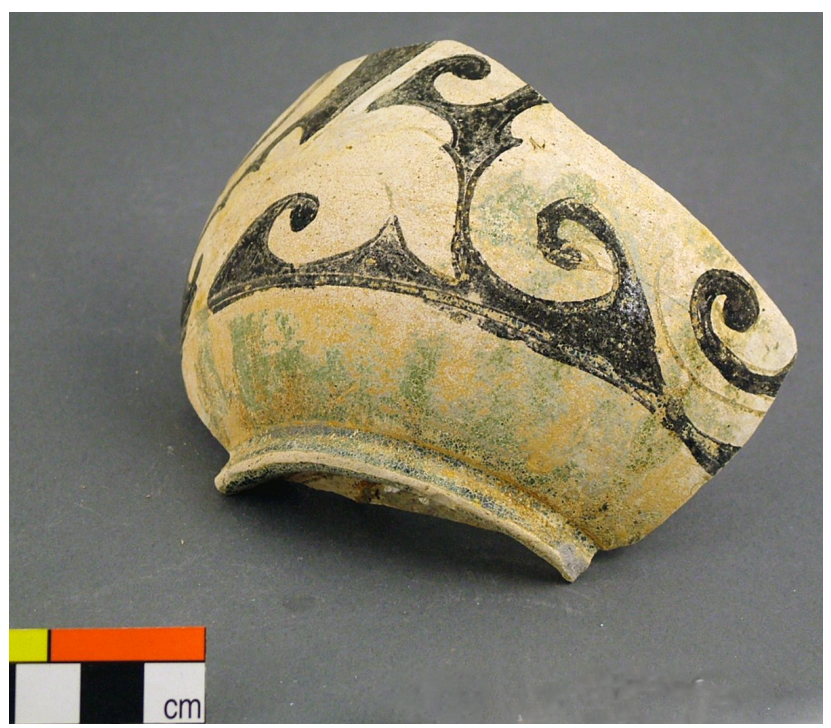

Figure 9: Painted ware ewer from the Java Sea Shipwreck (Pho to (C) The Field Museum, Catalog \#350418)
Although it is tempting to hypothesize that the Subgroup 1B samples came from the north because of their similarity to pieces produced at Cizhou kilns, recent kiln excavations at Wuyishan in Fujian have yielded ceramics that are very similar visually to the painted wares from the $J S W$ (Underwater Research Center of the National Museum of China, et al. 2015). Amounts of $\mathrm{Al}_{2} \mathrm{O}_{3}$ and $\mathrm{K}_{2} \mathrm{O}$ measured in the shipwreck pieces can be used to support a southern origin since another major determining factor of production region is the amount of $\mathrm{Al}_{2} \mathrm{O}_{3}$ and $\mathrm{K}_{2} \mathrm{O}$ (Pollard and Hatcher 1994). Pieces from the north are higher in $\mathrm{Al}_{2} \mathrm{O}_{3}$ (greater than 25 percent) and lower amounts of $\mathrm{K}_{2} \mathrm{O}$ (less than 2.5 percent). Southern ceramics have $\mathrm{Al}_{2} \mathrm{O}_{3}$ ranging from 10.3-24.5 percent and $\mathrm{K}_{2} \mathrm{O}$ close to 2.0-6.6 percent. This pattern also is observed by Wood (2011:28) and the $J S W$ ceramics fit the southern profile.

Findings presented by Zhu, et al. (2012) partially support these kiln assignments. They report that qingbai ceramics from Fujian province have amounts of $\mathrm{Al}_{2} \mathrm{O}_{3}$ and $\mathrm{Fe}_{2} \mathrm{O}_{3}$ ranging from 16.2-21.4 percent and 0.83-1.44 percent, respectively. The $J S W$ samples in Group 2 assigned to Dehua (in Fujian) have concentrations within these ranges. The average $\mathrm{Al}_{2} \mathrm{O}_{3}$ concentration for Group 2 is 17.30 percent and $\mathrm{Fe}_{2} \mathrm{O}_{3}$ is 0.99 percent. Zhu et al.'s work also may provide a clue as to from where the pieces in Subgroup $1 \mathrm{~B}$ are-Fujian, since the average $\mathrm{Al}_{2} \mathrm{O}_{3}$ concentration for this group is 19.92 percent and the average $\mathrm{Fe}_{2} \mathrm{O}_{3}$ concentration is 0.91 percent.

\section{Results and Discussion of the Glaze Analysis}

The materials used to make the bodies of the ceramics from the period and regions under discussion served as the main ingredients for the glazes (Pierson, et al. 2002; Wood 2011:29). Although there is mention in historical documents of a division of labor in ceramic production (So 1994:12), this has not yet been supported by archaeological evidence. Pieces appear to have been produced at multiple household workshops that engaged in all steps of the preparing, forming, and finishing process and then fed into a single kiln that accommodated the wares from multiple production units (So 1994:12). Most producers at the time tended to use local materials in manufacturing their goods (Zhu 2010:482), and both pastes and glazes have been used in sourcing studies (e.g., Leung, et al. 2000).

The geochemical data from LA-ICP-MS analysis of the glazes underwent similar statistical analysis, however, it was decided to keep the one painted ware sample out since it was clearly very different visually (bright green to oily black) and chemically (extremely high in $\mathrm{Pb}$ ) from the other glazes sampled. Because there were many fewer glaze samples than elements, the number of variables (elements) had to be reduced to facilitate statistical analysis. Biplots of the logged elemental values were examined to identify elements that would be potentially helpful for differentiating chemical groups. These include 19 elements: Li, U, Bi, Th, Ta, Yb, Gd, Na, La, Sb, Cs, Zr, Y, $\mathrm{Rb}, \mathrm{Sc}, \mathrm{K}, \mathrm{Ca}, \mathrm{B}$, and Be. PCA was performed on the logged

dataset. 
Table 5: Average elemental concentrations of chemical groups based on paste composition

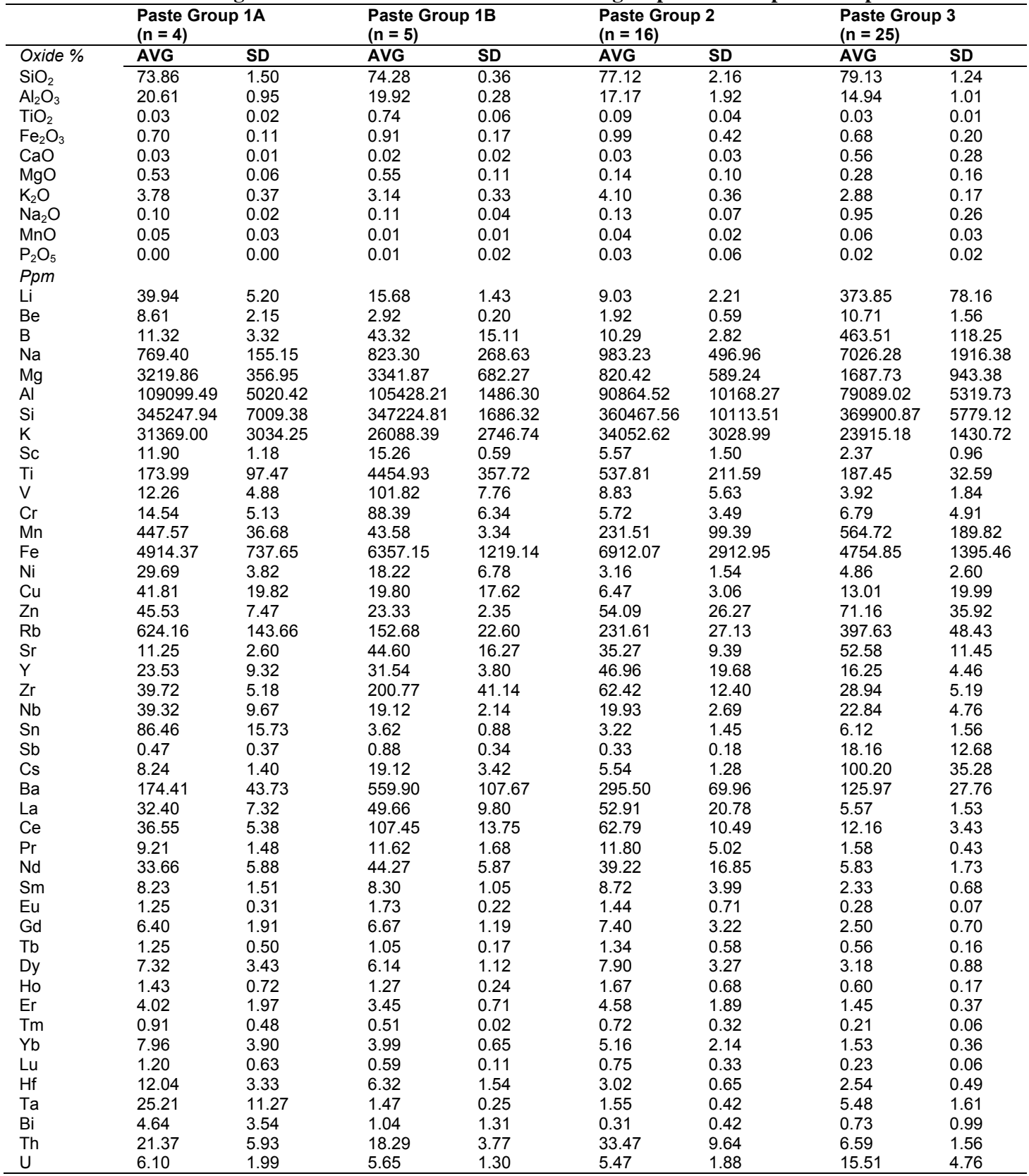



THE ARCHAEOLOGY OF EAST AND SOUTHEAST ASIA

Table 6: Possible kiln assignments of Java Sea Shipwreck ceramics (pastes) analyzed using LA-ICP-MS based on Leung and Luo's (2000) classification

\begin{tabular}{|c|c|c|c|c|c|c|c|c|c|}
\hline \multicolumn{10}{|c|}{ Parts-per-million } \\
\hline Sample & $\begin{array}{l}\text { Chem. } \\
\text { Grp. }\end{array}$ & $\mathbf{R b}$ & $\mathbf{Y}$ & $\mathrm{Zr}$ & $\mathrm{Zr} / \mathbf{R b}$ & $<1.29$ ? & $\begin{array}{l}0.79(\mathrm{Rb} / \mathrm{Y}+ \\
\mathrm{Zr} / \mathrm{Y})\end{array}$ & $>6$ ? & $\begin{array}{l}\text { Jingdezhen or } \\
\text { Dehua? }\end{array}$ \\
\hline JSW159 & $1 \mathrm{~A}$ & 814.98 & 21.73 & 40.21 & 0.05 & $\mathrm{Y}$ & 31.09 & $\mathrm{Y}$ & Jingdezhen \\
\hline JSW165 & $1 \mathrm{~A}$ & 608.55 & 36.46 & 39.86 & 0.07 & $Y$ & 14.05 & $Y$ & Jingdezhen \\
\hline JSW171 & $1 \mathrm{~A}$ & 606.94 & 14.21 & 45.73 & 0.08 & $Y$ & 36.28 & $Y$ & Jingdezhen \\
\hline \multirow[t]{2}{*}{ JSW173 } & $1 \mathrm{~A}$ & 466.16 & 21.72 & 33.08 & 0.07 & $Y$ & 18.16 & $\mathrm{Y}$ & Jingdezhen \\
\hline & AVG & 624.16 & 23.53 & 39.72 & 0.06 & $\mathbf{Y}$ & 22.29 & $\mathbf{Y}$ & Jingdezhen \\
\hline JSW129 & 1B & 183.53 & 37.67 & 264.18 & 1.44 & $\mathrm{~N}$ & 9.39 & $\mathrm{Y}$ & \\
\hline JSW169 & 1B & 147.19 & 30.97 & 191.38 & 1.30 & $\mathrm{~N}$ & 8.64 & $\mathrm{Y}$ & \\
\hline JSW174 & 1B & 155.23 & 28.68 & 163.25 & 1.05 & $\mathrm{Y}$ & 8.77 & $\mathrm{Y}$ & Jingdezhen \\
\hline JSW901 & 1B & 156.96 & 32.18 & 216.16 & 1.38 & $\mathrm{~N}$ & 9.16 & $\mathrm{Y}$ & \\
\hline \multirow[t]{2}{*}{ JSW904 } & 1B & 120.49 & 28.20 & 168.87 & 1.40 & $\mathrm{~N}$ & 8.11 & $\mathrm{Y}$ & \\
\hline & AVG & 152.68 & 31.54 & 200.77 & 1.31 & $\mathbf{N}$ & 8.85 & $\mathbf{Y}$ & $?$ \\
\hline JSW123 & 2 & 193.78 & 32.82 & 48.49 & 0.25 & $Y$ & 5.83 & $\mathrm{~N}$ & Dehua \\
\hline JSW154 & 2 & 252.21 & 70.54 & 49.65 & 0.20 & $\mathrm{Y}$ & 3.38 & $\mathrm{~N}$ & Dehua \\
\hline JSW188 & 2 & 245.35 & 42.60 & 76.42 & 0.31 & $\mathrm{Y}$ & 5.97 & $\mathrm{~N}$ & Dehua \\
\hline JSW196 & 2 & 251.25 & 42.17 & 67.12 & 0.27 & $\mathrm{Y}$ & 5.96 & $\mathrm{~N}$ & Dehua \\
\hline JSW198 & 2 & 209.31 & 72.93 & 59.15 & 0.28 & $\mathrm{Y}$ & 2.91 & $\mathrm{~N}$ & Dehua \\
\hline JSW199 & 2 & 271.77 & 23.07 & 69.81 & 0.26 & $\mathrm{Y}$ & 11.70 & $\mathrm{Y}$ & Jingdezhen \\
\hline JSW200 & 2 & 234.93 & 62.97 & 77.73 & 0.33 & $\mathrm{Y}$ & 3.92 & $\mathrm{~N}$ & Dehua \\
\hline JSW202 & 2 & 250.78 & 80.64 & 55.26 & 0.22 & $Y$ & 3.00 & $\mathrm{~N}$ & Dehua \\
\hline JSW203 & 2 & 192.70 & 52.04 & 43.42 & 0.23 & $Y$ & 3.58 & $\mathrm{~N}$ & Dehua \\
\hline JSW204 & 2 & 189.20 & 57.81 & 47.51 & 0.25 & $\mathrm{Y}$ & 3.23 & $\mathrm{~N}$ & Dehua \\
\hline JSW205 & 2 & 237.35 & 31.08 & 74.59 & 0.31 & $\mathrm{Y}$ & 7.93 & $\mathrm{Y}$ & Jingdezhen \\
\hline JSW206 & 2 & 262.74 & 15.45 & 79.16 & 0.30 & $\mathrm{Y}$ & 17.48 & $\mathrm{Y}$ & Jingdezhen \\
\hline JSW207 & 2 & 214.06 & 35.49 & 57.27 & 0.27 & $\mathrm{Y}$ & 6.04 & $\mathrm{Y}$ & Dehua \\
\hline \multirow[t]{2}{*}{ JSW208 } & 2 & 237.18 & 37.89 & 68.25 & 0.29 & $\mathrm{Y}$ & 6.37 & $\mathrm{Y}$ & Dehua \\
\hline & AVG & 231.61 & 46.96 & 62.42 & 0.27 & $\mathbf{Y}$ & 4.95 & $\mathbf{N}$ & Dehua \\
\hline JSW126 & 3 & 434.60 & 20.14 & 34.72 & 0.08 & $Y$ & 18.41 & $Y$ & Jingdezhen \\
\hline JSW127 & 3 & 525.66 & 28.76 & 41.26 & 0.08 & $Y$ & 15.57 & $Y$ & Jingdezhen \\
\hline JSW131 & 3 & 376.81 & 19.98 & 27.41 & 0.07 & $\mathrm{Y}$ & 15.98 & $\mathrm{Y}$ & Jingdezhen \\
\hline JSW133 & 3 & 363.07 & 11.63 & 22.90 & 0.06 & $\mathrm{Y}$ & 26.23 & $\mathrm{Y}$ & Jingdezhen \\
\hline JSW136 & 3 & 383.14 & 21.12 & 39.83 & 0.10 & $\mathrm{Y}$ & 15.82 & $\mathrm{Y}$ & Jingdezhen \\
\hline JSW137 & 3 & 371.83 & 19.88 & 32.42 & 0.09 & $Y$ & 16.06 & $Y$ & Jingdezhen \\
\hline JSW138 & 3 & 334.95 & 12.53 & 24.93 & 0.07 & $Y$ & 22.69 & $\mathrm{Y}$ & Jingdezhen \\
\hline JSW139 & 3 & 336.42 & 12.30 & 29.39 & 0.09 & Y & 23.49 & $\mathrm{Y}$ & Jingdezhen \\
\hline JSW151 & 3 & 394.48 & 18.99 & 26.57 & 0.07 & $\mathrm{Y}$ & 17.52 & Y & Jingdezhen \\
\hline JSW152 & 3 & 513.08 & 15.60 & 30.59 & 0.06 & $\mathrm{Y}$ & 27.54 & $\mathrm{Y}$ & Jingdezhen \\
\hline JSW153 & 3 & 410.22 & 11.58 & 28.51 & 0.07 & $\mathrm{Y}$ & 29.93 & $\mathrm{Y}$ & Jingdezhen \\
\hline JSW156 & 3 & 381.51 & 16.52 & 28.20 & 0.07 & $Y$ & 19.60 & $\mathrm{Y}$ & Jingdezhen \\
\hline JSW157 & 3 & 425.35 & 11.19 & 25.38 & 0.06 & $\mathrm{Y}$ & 31.83 & $\mathrm{Y}$ & Jingdezhen \\
\hline JSW161 & 3 & 378.88 & 14.28 & 35.43 & 0.09 & $\mathrm{Y}$ & 22.91 & $\mathrm{Y}$ & Jingdezhen \\
\hline JSW163 & 3 & 431.25 & 11.72 & 22.90 & 0.05 & $Y$ & 30.60 & $\mathrm{Y}$ & Jingdezhen \\
\hline JSW168 & 3 & 332.69 & 8.15 & 18.74 & 0.06 & $\mathrm{Y}$ & 34.08 & $\mathrm{Y}$ & Jingdezhen \\
\hline JSW189 & 3 & 358.62 & 16.88 & 29.96 & 0.08 & $\mathrm{Y}$ & 18.19 & $\mathrm{Y}$ & Jingdezhen \\
\hline JSW190 & 3 & 436.17 & 18.03 & 31.51 & 0.07 & $Y$ & 20.49 & $Y$ & Jingdezhen \\
\hline JSW191 & 3 & 358.88 & 18.03 & 25.93 & 0.07 & $Y$ & 16.86 & $Y$ & Jingdezhen \\
\hline JSW192 & 3 & 394.16 & 11.49 & 26.63 & 0.07 & $\mathrm{Y}$ & 28.92 & $\mathrm{Y}$ & Jingdezhen \\
\hline JSW194 & 3 & 435.50 & 18.37 & 23.23 & 0.05 & $\mathrm{Y}$ & 19.73 & $\mathrm{Y}$ & Jingdezhen \\
\hline JSW195 & 3 & 419.83 & 18.89 & 26.91 & 0.06 & $Y$ & 18.68 & $\mathrm{Y}$ & Jingdezhen \\
\hline JSW201 & 3 & 382.24 & 17.54 & 29.34 & 0.08 & $\mathrm{Y}$ & 18.54 & $\mathrm{Y}$ & Jingdezhen \\
\hline JSW900 & 3 & 401.57 & 19.23 & 32.25 & 0.08 & $Y$ & 17.82 & $\mathrm{Y}$ & Jingdezhen \\
\hline \multirow[t]{2}{*}{ JSW902 } & 3 & 359.92 & 13.44 & 28.66 & 0.08 & Y & 22.85 & Y & Jingdezhen \\
\hline & AVG & 397.63 & 16.25 & 28.94 & 0.07 & $\mathbf{Y}$ & 20.74 & $\mathbf{Y}$ & Jingdezhen \\
\hline
\end{tabular}


The first four PCs have eigenvalues greater than one, accounting for more than 89 percent of the elemental variance in the dataset. Over the course of the statistical analysis, it became apparent that JSW186 (qingbai) along with JSW212 and JSW209 (qingbai-style) were outliers to their respective style groups. Because each of these samples has a group membership probability based on Mahalanobis distance calculations of less than one percent in the group containing samples of similar style, they were removed from further analysis. Through the analysis, it also became clear that the qingbai-style glazes fell into two chemical subgroups.

Overall, the glaze chemical groups correspond very well with ceramic style (qingbai, qingbai-style, and green-glazed). Table 7 provides the average elemental concentrations for the different glaze groups. Whereas it is difficult to distinguish between green-glazed and qingbai-style pieces using paste composition, these two styles clearly separate based on their glaze compositions (Figure 10). Group 1, comprised of qingbai pieces, is distinguished by higher concentrations of $\mathrm{Li}, \mathrm{Be}, \mathrm{B}, \mathrm{Sb}$, and $\mathrm{Cs}$ and lower concentrations of $\mathrm{Sc}, \mathrm{Y}, \mathrm{Zr}$, and the rare earth elements. The members of this group match those in paste Group 3, hypothesized to have come from Jingdezhen. The major element concentrations of this group correspond with those reported by Wood (2011) for Jingdezhen qingbai glazes (and pastes). Glaze Group 3, predominantly green-glazed ware, is a small group with higher amounts of $\mathrm{Mg}, \mathrm{Mn}, \mathrm{P}, \mathrm{Ti}, \mathrm{V}, \mathrm{Mn}, \mathrm{Ba}$, and $\mathrm{Pb}$ and is lower in $\mathrm{Ca}$ and $\mathrm{Ni}$. The majority of members of this group are from samples assigned to Dehua based on paste composition. Glaze Group 2 is higher in $\mathrm{Al}, \mathrm{Nb}$, and $\mathrm{Sn}$ and lower in $\mathrm{Sb}$. It can be divided into two subgroups of qingbai-style pieces. Subgroup 2A has higher amounts of $\mathrm{Ni}$, $\mathrm{Cu}, \mathrm{Rb}, \mathrm{Nb}, \mathrm{Sn}, \mathrm{Yb}, \mathrm{Lu}, \mathrm{Hf}$, and $\mathrm{Ta}$ and lower amounts of Ti. Two samples in this group of four are covered boxes that are slightly different than other boxes in terms of style-instead of having ribbing or being octagonal in shape with decorated lids, these pieces are smooth, round, and undecorated (Figure 11). Subgroup 2B has higher concentrations of $\mathrm{La}, \mathrm{Nd}, \mathrm{Sm}, \mathrm{Eu}$, and $\mathrm{Gd}$ and lower concentrations of $\mathrm{Zn}$ and $\mathrm{Rb}$. Because there is not a lot of overlap between the glaze Group 2 samples and paste samples that were run, it is difficult to make a production assignment at this time; however, Wood (2011) notes that some Dehua qingbai-type ceramics had $\mathrm{CaO}$ content ranging from 10-12.5 percent. Both glaze Subgroups 2A and $2 \mathrm{~B}$ have $\mathrm{CaO}$ concentrations closest to this range. At the same time, some Dehua glazes, including pale green ones like those found on the JSW's green-glazed bowls, could have very low $\mathrm{CaO}$ amounts (only about 5-7 percent) (Wood 2011). The samples in glaze Group 3 have very low $\mathrm{CaO}$ concentrations (averaging 3.66 percent) and, based on their paste composition, are possibly from Dehua.

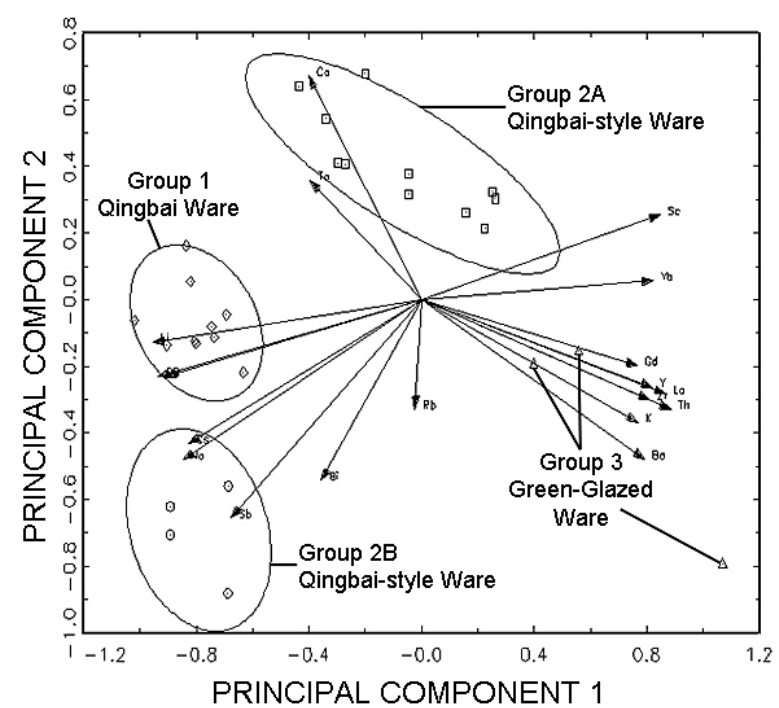

Figure 10: $R$-Q mode biplot of principal components 1 and 2 based on glaze compositions. Ellipses represent 90 percent confidence intervals. Diamonds represent qingbai samples (Group 1), squares (Group 2A) and circles (Group 2B) are qingbai-style pieces, and triangles are green-glazed samples (Group 3).

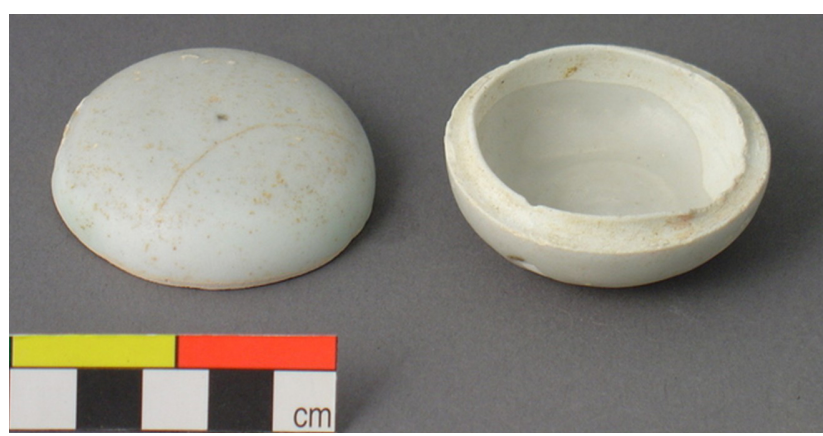

Figure 11: Qingbai-style undecorated covered box from the Java Sea Shipwreck (Photo (C) The Field Museum, Catalog \#344282)

\section{CONCLUSION}

This paper has examined the results of LA-ICP-MS analysis of a sample of high-fired ceramics from the twelfththirteenth-century Java Sea Shipwreck. Using major, minor, and trace elemental concentrations, three (possibly four) groups were identified using the paste data and four groups emerged using the glaze data. Through the analysis, ceramic group memberships based on visual assessments of style were able to be tested and refined. For example, one vase neck or rim (JSW214) which was originally thought to be qingbai is more compositionally similar to the qingbai-style pieces. In addition, painted wares that initially appear to be from the same production area are more likely from two, based on the chemical compositions of their pastes. Furthermore, the possibility of one of these subgroups being from the north cannot be entirely ruled out and presents an intriguing idea requiring additional research. 
Table 7: Average elemental concentrations of chemical groups based on glaze composition

\begin{tabular}{|c|c|c|c|c|c|c|c|c|}
\hline \multirow[b]{2}{*}{ Oxide \% } & \multicolumn{2}{|c|}{$\begin{array}{l}\text { Glaze Group } 1 \\
(\mathrm{n}=10)\end{array}$} & \multicolumn{2}{|c|}{$\begin{array}{l}\text { Glaze Group 2A } \\
(n=4)\end{array}$} & \multicolumn{2}{|c|}{$\begin{array}{l}\text { Glaze Group 2B } \\
(\mathrm{n}=11)\end{array}$} & \multicolumn{2}{|c|}{$\begin{array}{l}\text { Glaze Group } 3 \\
(n=3)\end{array}$} \\
\hline & AVG & SD & AVG & SD & AVG & SD & AVG & SD \\
\hline $\mathrm{SiO}_{2}$ & 66.85 & 1.91 & 66.54 & 2.34 & 67.78 & 1.94 & 73.47 & 2.68 \\
\hline $\mathrm{Al}_{2} \mathrm{O}_{3}$ & 14.18 & 0.80 & 15.55 & 1.26 & 15.55 & 1.82 & 14.22 & 2.88 \\
\hline $\mathrm{TiO}_{2}$ & 0.03 & 0.01 & 0.01 & 0.01 & 0.04 & 0.02 & 0.09 & 0.02 \\
\hline $\mathrm{Fe}_{2} \mathrm{O}_{3}$ & 0.89 & 0.15 & 0.44 & 0.15 & 0.42 & 0.20 & 0.69 & 0.21 \\
\hline $\mathrm{CaO}$ & 13.62 & 2.09 & 12.69 & 1.71 & 12.12 & 1.89 & 3.66 & 0.48 \\
\hline $\mathrm{MgO}$ & 0.31 & 0.11 & 0.36 & 0.17 & 0.33 & 0.20 & 0.61 & 0.04 \\
\hline $\mathrm{K}_{2} \mathrm{O}$ & 2.19 & 0.27 & 3.77 & 0.21 & 3.32 & 0.48 & 5.79 & 0.09 \\
\hline $\mathrm{Na}_{2} \mathrm{O}$ & 1.18 & 0.35 & 0.10 & 0.03 & 0.08 & 0.02 & 0.42 & 0.11 \\
\hline $\mathrm{MnO}$ & 0.11 & 0.03 & 0.10 & 0.03 & 0.12 & 0.07 & 0.23 & 0.02 \\
\hline $\mathrm{P}_{2} \mathrm{O}_{5}$ & 0.10 & 0.05 & 0.14 & 0.08 & 0.11 & 0.14 & 0.35 & 0.11 \\
\hline \multicolumn{9}{|l|}{ Ppm } \\
\hline $\mathrm{Li}$ & 953.34 & 309.26 & 87.20 & 10.69 & 31.52 & 10.80 & 32.94 & 25.61 \\
\hline $\mathrm{Be}$ & 19.14 & 6.17 & 3.49 & 0.43 & 1.89 & 0.80 & 3.55 & 0.87 \\
\hline B & 271.72 & 53.70 & 22.60 & 10.14 & 18.61 & 7.32 & 22.78 & 10.78 \\
\hline $\mathrm{Na}$ & 8733.07 & 2574.77 & 734.82 & 214.87 & 613.04 & 121.70 & 3148.16 & 805.78 \\
\hline $\mathrm{Mg}$ & 1877.60 & 674.50 & 2165.18 & 997.47 & 1981.45 & 1176.14 & 3672.19 & 228.10 \\
\hline $\mathrm{Al}$ & 75025.71 & 4210.86 & 82315.72 & 6665.98 & 82311.37 & 9619.43 & 75235.55 & 15218.33 \\
\hline $\mathrm{Si}$ & 312468.35 & 8942.62 & 311029.82 & 10951.46 & 316852.43 & 9086.46 & 343441.85 & 12514.02 \\
\hline$P$ & 427.71 & 239.31 & 626.49 & 365.61 & 459.85 & 600.71 & 1547.90 & 495.37 \\
\hline K & 18181.64 & 2236.78 & 31333.42 & 1730.14 & 27573.86 & 3949.09 & 48092.03 & 752.84 \\
\hline $\mathrm{Ca}$ & 97318.51 & 14907.12 & 90656.80 & 12196.61 & 86571.74 & 13472.48 & 26127.84 & 3422.85 \\
\hline Sc & 1.44 & 0.52 & 6.92 & 0.48 & 5.69 & 0.55 & 4.46 & 0.63 \\
\hline $\mathrm{Ti}$ & 156.76 & 66.38 & 41.41 & 36.04 & 239.45 & 99.25 & 543.23 & 113.86 \\
\hline $\mathrm{V}$ & 11.47 & 3.96 & 9.27 & 2.22 & 9.02 & 2.94 & 22.65 & 18.67 \\
\hline $\mathrm{Cr}$ & 11.84 & 7.94 & 8.93 & 0.78 & 7.87 & 3.48 & 4.33 & 4.31 \\
\hline $\mathrm{Mn}$ & 826.06 & 230.50 & 789.64 & 240.08 & 957.78 & 534.18 & 1802.07 & 148.71 \\
\hline $\mathrm{Fe}$ & 6245.70 & 1070.23 & 3093.37 & 1041.15 & 2971.77 & 1396.89 & 4840.21 & 1471.31 \\
\hline $\mathrm{Ni}$ & 18.24 & 9.75 & 42.89 & 20.73 & 12.97 & 5.15 & 6.80 & 2.11 \\
\hline $\mathrm{Cu}$ & 33.75 & 13.92 & 85.98 & 33.36 & 18.60 & 8.17 & 21.18 & 6.56 \\
\hline $\mathrm{Zn}$ & 98.61 & 35.77 & 112.66 & 119.66 & 43.08 & 30.03 & 91.42 & 14.23 \\
\hline $\mathrm{Rb}$ & 225.74 & 28.61 & 409.30 & 71.57 & 177.11 & 33.23 & 297.09 & 106.74 \\
\hline $\mathrm{Sr}$ & 179.57 & 46.13 & 317.27 & 135.07 & 260.78 & 55.40 & 311.06 & 174.12 \\
\hline $\mathrm{Y}$ & 17.92 & 4.97 & 16.73 & 2.83 & 50.61 & 18.78 & 40.92 & 11.18 \\
\hline $\mathrm{Zr}$ & 28.06 & 6.42 & 26.57 & 4.50 & 75.57 & 12.25 & 85.00 & 66.21 \\
\hline $\mathrm{Nb}$ & 23.93 & 5.44 & 89.60 & 10.72 & 43.07 & 19.98 & 23.98 & 7.89 \\
\hline Sn & 5.30 & 1.96 & 19.66 & 12.07 & 2.26 & 1.50 & 6.17 & 2.64 \\
\hline $\mathrm{Sb}$ & 9.69 & 3.82 & 0.16 & 0.14 & 0.21 & 0.17 & 2.55 & 2.82 \\
\hline Cs & 31.85 & 10.83 & 2.90 & 0.60 & 3.14 & 0.97 & 5.06 & 2.22 \\
\hline $\mathrm{Ba}$ & 133.33 & 40.82 & 294.98 & 189.19 & 384.86 & 152.34 & 1266.31 & 889.60 \\
\hline La & 11.23 & 8.54 & 12.98 & 8.17 & 82.91 & 54.29 & 59.09 & 10.77 \\
\hline $\mathrm{Ce}$ & 23.72 & 21.58 & 18.73 & 5.05 & 60.29 & 19.14 & 59.36 & 14.50 \\
\hline $\mathrm{Pr}$ & 2.68 & 1.77 & 3.54 & 2.33 & 16.27 & 9.31 & 10.82 & 1.70 \\
\hline $\mathrm{Nd}$ & 10.13 & 7.06 & 12.22 & 7.66 & 57.74 & 32.70 & 37.07 & 5.30 \\
\hline Sm & 2.95 & 1.38 & 4.06 & 1.85 & 11.95 & 6.46 & 6.75 & 1.45 \\
\hline Eu & 0.34 & 0.26 & 0.29 & 0.21 & 2.35 & 1.55 & 1.42 & 0.34 \\
\hline $\mathrm{Gd}$ & 2.84 & 1.26 & 2.96 & 0.85 & 9.22 & 4.81 & 4.97 & 2.22 \\
\hline $\mathrm{Tb}$ & 0.67 & 0.24 & 0.83 & 0.19 & 1.51 & 0.69 & 1.79 & 1.29 \\
\hline Dy & 3.56 & 1.21 & 5.84 & 1.33 & 8.60 & 3.50 & 6.43 & 1.97 \\
\hline $\mathrm{Ho}$ & 0.56 & 0.21 & 1.16 & 0.24 & 1.74 & 0.63 & 1.24 & 0.29 \\
\hline $\mathrm{Er}$ & 1.50 & 0.50 & 3.79 & 0.91 & 4.49 & 1.55 & 3.67 & 1.04 \\
\hline $\mathrm{Tm}$ & 0.21 & 0.09 & 0.79 & 0.13 & 0.66 & 0.19 & 0.46 & 0.19 \\
\hline $\mathrm{Yb}$ & 1.56 & 0.59 & 8.37 & 1.85 & 4.74 & 1.24 & 4.97 & 1.68 \\
\hline Lu & 0.16 & 0.10 & 1.10 & 0.28 & 0.63 & 0.16 & 0.52 & 0.10 \\
\hline $\mathrm{Hf}$ & 2.03 & 0.84 & 5.08 & 1.43 & 3.44 & 0.49 & 2.91 & 1.74 \\
\hline $\mathrm{Ta}$ & 4.08 & 1.24 & 20.79 & 3.82 & 1.50 & 0.40 & 0.97 & 0.37 \\
\hline $\mathrm{Pb}$ & 63.12 & 54.89 & 39.75 & 36.91 & 50.27 & 45.41 & 266.04 & 208.67 \\
\hline $\mathrm{Bi}$ & 2.60 & 4.89 & 1.58 & 2.58 & 0.23 & 0.49 & 3.40 & 3.65 \\
\hline Th & 6.09 & 3.18 & 8.75 & 0.91 & 23.91 & 6.54 & 29.96 & 15.50 \\
\hline$U$ & 16.50 & 6.93 & 7.13 & 0.72 & 4.11 & 0.89 & 10.12 & 9.43 \\
\hline
\end{tabular}


Comparing the data generated by this project to data from other compositional studies on Chinese ceramics, two southern production areas for the $J S W$ high-fired ceramics made in the qingbai tradition were able to be preliminarily identified: Jingdezhen in Jiangxi province and Dehua in Fujian province. Ho (1994a:xi) suggests that by looking at smaller kiln sites-as well as larger ones-we can investigate their role in the export market, competition, distribution patterns and mechanisms, and the organization of the Chinese economy at the time. Information such as that generated by this project will be useful not only for learning more about the products of each of these areas but also for reconstructing distribution networks in China and investigating how these were linked to larger interregional trade systems using comparative archaeological data terrestrial and other maritime sites.

\section{ACKNOWLEDGMENTS}

This material is based upon work undertaken at The Field Museum in Chicago that was supported by the Commander Gilbert E. Boone and Katharine Phelps Boone family. Much of this research would not have been possible without the support of Anthropology colleagues, volunteers, and interns at The Field Museum. I'd especially like to acknowledge the assistance and support of Jamie Kelly, Laure Dussubieux, Gary M. Feinman, Ryan Williams, David Quednau, and Chapurukha Kusimba (now at American University in Washington, DC). I am grateful, too, to Nam Kim and Alison Carter for inviting me to participate in the Henry Luce Foundation conference, Recent Advances in the Archaeology of East and Southeast Asia, held at University of Wisconsin-Madison, March 15-16, 2013, where I originally presented this paper. I also am indebted to two anonymous reviewers, who provided kind and constructive criticism of an earlier draft of this manuscript.

\section{REFERENCES}

Bao, Y., B. Liao, and L. Lane. 2006. Renaissance in China: The Culture and Art of the Song Dynasty 907-1279. Lewiston, NY: The Edwin Mellen Press.

Baxter, M.J. 2001. Multivariate analysis in archaeology. In D.R. Brothwell and A.M. Pollard (eds.), Handbook of Archaeological Sciences, pp. 685-694. Chichester: John Wiley \& Sons, Ltd.

Bronson, B. 1997. The iron industry and trade. In W.M. Mathers and M. Flecker (eds.), Archaeological Recovery of the Java Sea Wreck, pp. 95-102. Annapolis, MD: Pacific Sea Resources.

Brown, R. 1997a. High-fired ceramics of Song Dynasty China: the Java Sea cargo in context. In W.M. Mathers and M. Flecker (eds.), Archaeological Recovery of the Java Sea Wreck, pp. 103-109. Annapolis, MD: Pacific Sea Resources.

Brown, R. 1997b. Thirteenth century potting techniques: as evidenced by the Java Sea cargo. In W.M. Mathers and M. Flecker (eds.), Archaeological Recovery of the Java Sea Wreck, pp. 110-115. Annapolis, MD: Pacific Sea Resources.
Chaudhuri, K.N. 1985. Trade and Civilisation in the Indian Ocean: An Economic History from the Rise of Islam to 1750. Cambridge: Cambridge University Press.

Deng, G. 1997. Chinese Maritime Activities and Socioeconomic Development, c. 2100 B.C.-1900 A.D. Westport, CT: Greenwood Press. Volume 188.

Descantes, C., H. Neff, and M.D. Glascock. 2002. Yapese prestige goods: the INAA evidence for an Asian dragon jar. In M.D. Glascock (ed.), Geochemical Evidence for Long-distance Exchange, pp. 229-256. Scientific Archaeology for the Third Millennium Series. Westport, CT: Bergin and Garvey.

Diem, A.I. 2004. Ceramic evidence of ancient maritime relationships between central Viet Nam and the Philippine archipelago. In V. Paz (ed.), Southeast Asian Archaeology: Wilhelm G. Solheim II Festschrift, pp. 463490. Diliman, Quezon City, Philippines: The University of the Philippines Press.

Dizon, E.Z. 2011.Shipwreck site and earthenware vessels in the Philippines: earthenware vessels of the Pandanan Shipwreck site, Asia-Pacific Regional Conference on Underwater Cultural Heritage. Manila, Philippines: Museum of Underwater Archaeology.

Dreyer, E.L. 2007. Zheng He: China and the Oceans in the Early Ming Dynasty, 1405-1433. New York: Pearson Longman.

Dunn, R.E. 1989. The Adventures of Ibn Battuta: A Muslim Traveler of the 14th Century. Berkeley: University of California Press.

Dupoizat, M.-F. 1995. The ceramic cargo of a Song Dynasty junk found in the Philippines and its significance in the China-South East Asia trade. In R. Scott and J. Guy (eds.), South East Asia and China: Art, Interaction and Commerce, pp. 205-224. London, England: Percival David Foundation of Chinese Art.

Dussubieux, L. , M. Golitko, P.R. Williams, and R.J. Speakman. 2007. LA-ICP-MS analysis applied to the characterization of Peruvian Wari ceramics. In M.D. Glascock, R.J. Speakman, and R.W. Popelka-Filcoff (eds.), Archaeological Chemistry: Analytical Techniques and Archaeological Interpretation, pp. 349-363. Oxford: Oxford University Press.

Eerkens, J.W., H. Neff, and M.D. Glascock. 2002. Ceramic production among small-scale and mobile hunters and gatherers: a case study from the Western Great Basin. Journal of Anthropological Archaeology 21(2):200-229.

Flecker, M. 2001. A ninth-century AD Arab or Indian shipwreck in Indonesia: first evidence for direct trade with China. World Archaeology 32(3):335-354.

Flecker, M. 2003. The thirteenth-century Java Sea Wreck: a Chinese cargo in an Indonesian ship. The Mariner's Mirror 89(4):388-404.

Flecker, M. 2005.The advent of Chinese sea-going shipping: a look at the shipwreck evidence, International Conference: Chinese Export Ceramics and Maritime Trade, 12th 15th Centuries, Hong Kong, June 24-25, 2004, pp. 143162. Hong Kong: City University of Hong Kong.

Flecker, M. 2005-2006. Rescue excavation: the Java Sea Wreck. Heritage Asia 3(2):25-29.

Fox, R.B., and A. Legaspi. 1977. Excavations at Santa Ana. Manila: National Museum Publications. 
Glascock, M.D., H. Neff, and K.J. Vaughn. 2004. Instrumental neutron activation analysis and multivariate statistics for pottery provenance. Hyperfine Interactions 154:95-105.

Grave, P., L. Lisle, and M. Maccheroni. 2005. Multivariate comparison of ICP-OES and PIXE/PIGE analysis of East Asian storage jars. Journal of Archaeological Science 32:885-896

Guy, J.S. 1986. Oriental Trade Ceramics in South-East Asia Ninth to Sixteenth Centuries. Singapore: Oxford University Press.

Hall, K.R. 1985. Maritime Trade and State Development in Early Southeast Asia. Honolulu: University of Hawaii Press.

Hall, K.R. 1999. Economic history of early Southeast Asia. In N. Tarling (ed.), Cambridge History of Southeast Asia, Volume 1, from Early Times to c. 1500, pp. 183-275. Cambridge: Cambridge University Press.

Hall, K.R. 2011. A History of Early Southeast Asia: Maritime Trade and Societal Development, 100-1500. Lanham, MD: Rowman \& Littlefield Publishers, Inc.

Hall, K.R., and J.K. Whitmore. 1976. Southeast Asian trade and the isthmian struggle, 1000-1200 A.D. In K.R. Hall and J.K. Whitmore (eds.), Explorations in Early Southeast Asian History: The Origins of Southeast Asian Statecraft, pp. 303-340. Michigan Papers on South and Southeast Asia. Vol. 11. Ann Arbor: Center for South and Southeast Asian Studies, The University of Michigan.

Ho, C. 1994a. The production and distribution of Zhejiang green glazed wares: preface to the conference proceedings. In C. Ho (ed.), New Light on Chinese Yue and Longquan Wares: Archaeological Ceramics Found in Eastern and Southern Asia, A.D. 800-1400, pp. ix-xxvi. Hong Kong: Center of Asian Studies, The University of Hong Kong.

Ho, C. 1994b. Yue-type and Longquan-type green glazed wares made outside Zhejiang Province. In C. Ho (ed.), New Light on Chinese Yue and Longquan Wares: Archaeological Ceramics Found in Eastern and Southern Asia, A.D. 800-1400, pp. 103-119. Hong Kong: Center of Asian Studies, The University of Hong Kong.

Hughes-Stanton, P., and R. Kerr. 2000. Kiln Sites of Ancient China: Recent Finds of Pottery and Porcelain. London: Oriental Ceramic Society.

Junker, L.L. 1999. Raiding, Trading, and Feasting: The Political Economy of Philippine Chiefdoms. Honolulu, HI: University of Hawaii Press.

Junker, L.L. 2004. Political economy in the historic period chiefdoms and states of Southeast Asia. In G.M. Feinman and L.M. Nicholas (eds.), Archaeological Perspectives on Political Economies, pp. 223-251. Foundations of Archaeological Inquiry. Salt Lake City: The University of Utah Press.

Kauz, R. (ed.). 2010. Aspects of the Maritime Silk Road: From the Persian Gulf to the East China Sea. Wiesbaden: Harrassowitz Verlag.

Kennett, D.J., J. Anderson, M.J. Cruz, G.R. Clark, and G.R. Summerhayes. 2004. Geochemical characterization of Lapita pottery via inductively coupled plasma-mass spectrometry (ICP-MS). Archaeometry 46(1):35-46.

Krahl, R. 2010. Chinese ceramics in the late Tang Dynasty. In R. Krahl, J. Guy, K.J. Wilson, and J. Raby (eds.), Shipwrecked: Tang Treasures and Monsoon Winds, pp. 56-73. Washington, DC: Arthur M. Sackler Gallery,
Smithsonian Institution, National Heritage Board, and Singapore Tourism Board.

Krahl, R., J. Guy, K.J. Wilson, and J. Raby (eds.). 2010. Shipwrecked: Tang Treasures and Monsoon Winds. Washington, DC: Arthur M. Sackler Gallery, Smithsonian Institution, National Heritage Board, and Singapore Tourism Board.

Kusimba, C.M. 1999. The Rise and Fall of Swahili States. Walnut Creek, CA: Altamira Press.

Leung, P.L., and H. Luo. 2000. A study of provenance and dating of ancient Chinese porcelain by X-ray fluorescence spectrometry. X-Ray Spectrometry 29:34-38.

Leung, P.L., M.J. Stokes, T. Chen, and D. Qin. A sudy of ancient Chinese porcelain wares of the Song-Yuan dynasties from Cizhou and Ding kilns with energy dispersive X-ray fluorescence. Archaeometry 42(1):129140.

Li, B., A. Greig, J.-X. Zhao, K.D. Collerson, K.-S. Quan, Y.-H. Meng, and Z.-L. Ma. 2005. ICP-MS trace element analysis of Song Dynasty porcelains from Ding, Jiexiu and Guantai kilns, north China. Journal of Archaeological Science 32:251-259.

Li, B., J.-X. Zhao, K.D. Collerson, and A. Greig. 2003. Application of ICP-MS trace element analysis in study of ancient Chinese ceramics. Chinese Science Bulletin 48(12):1219-1224.

Li, B., J.-X. Zhao, A. Greig, K.D. Collerson, Y.-X. Feng, X.-M. Sun, M.-S. Guo, and Z.-X. Zhuo. 2006. Characterisation of Chinese Tang sancai from Gongxian and Yaozhou kilns using ICP-MS trace element and TIMS Sr-Nd isotopic analysis. Journal of Archaeological Science 33:56-62.

Li, Q. 2009. Nanhai I and the Maritime Silk Road. Beijing: China Intercontinental Press.

Manguin, P.-Y. 1993. Trading ships of the South China Sea: shipbuilding techniques and their role in the development of Asian trade networks. Journal of the Economic and Social History of the Orient 36:253-280.

Manguin, P.-Y. 2004. The archaeology of early maritime polities of Southeast Asia. In I. Glover and P. Bellwood (eds.), Southeast Asia: From Prehistory to History, pp. 282-313. London: RoutledgeCurzon.

Mathers, W.M., and M. Flecker (eds.). 1997. Archaeological Recovery of the Java Sea Wreck. Annapolis, MD: Pacific Sea Resources.

Miksic, J. 1997. Historical background. In W.M. Mathers and M. Flecker (eds.), Archaeological Recovery of the Java Sea Wreck, pp. 5-33. Annapolis, MD: Pacific Sea Resources.

Miksic, J. Recent research in the southeast Sumatran region, Asia-Pacific Regional Conference on Underwater Cultural Heritage Proceedings. Manila, Philippines.

Miksic, J.N., and C.T. Yap. 1992. Compositional analysis of pottery from Kota Cina, north Sumatra: implications for regional trade during the twelth to fourteenth centuries A.D. Asian Perspectives 31(1):57-76.

Miksic, J.N., C.T. Yap, and H. Younan. 1994. Archaeology and early Chinese glass trade in Southeast Asia. Journal of Southeast Asian Studies 25(1):31-46.

Mino, Y. 1992. Recent finds of Chinese Song and Yuan ceramics. In G. Kuwayama (ed.), New Perpsectives on the 
Art of Ceramics in China, pp. 14-53. Los Angeles: Far Eastern Council, Los Angeles County Museum of Art.

Mino, Y., and P. Wilson. 1973. An Index to Chinese Ceramic Kiln Sites from the Six Dynasties to the Present. Toronto: Royal Ontario Museum.

Neff, H. 1994. RQ-mode principal components analysis of ceramic compositional data. Archaeometry 36:115-130.

Nishimura, M. 1992. Long Distance Trade and the Development of Complex Societies in the Prehistory of the Central Philippines: The Cebu Central Settlement Case. Doctoral dissertation, Anthropology, University of Michigan, Ann Arbor.

Niziolek, L.C. 2013a. Earthenware production and distribution in the prehispanic Philippine polity of Tanjay: results from laser ablation-inductively coupled plasma-mass spectrometry (LA-ICP-MS). Journal of Archaeological Science 40:2824-2839.

Niziolek, L.C. 2013b. Examining changes in the organization of earthenware production in a prehispanic Philippine polity using LA-ICP-MS. Open Journal of Archaeometry 1(1):115 .

Oka, R., L. Dussubieux, C.M. Kusimba, and V.D. Gogte. 2009. The impact of imitation ceramic industries and internal political restrictions on Chinese commercial ceramic exports in the Indian Ocean maritime exchange, ca. 12001700, Scientific Research on Historic Asian Ceramics: Proceedings of the Fourth Forbes Symposium at the Freer Gallery of Art, pp. 175-185. London: Archetype Publications.

Phillips, J.G. 1956. China-Trade Porcelain. Cambridge, MA: Harvard University Press.

Pollard, A.M., and H. Hatcher. 1994. The chemical analysis of Oriental ceramic body compositions: part 1: wares from north China. Archaeometry 36(1):41-62.

Reid, A. 1988a. Southeast Asia in the Age of Commerce 14501680, Volume 1: The Lands below the Winds. New Haven: Yale University Press.

Reid, A. 1988b. Southeast Asia in the Age of Commerce 14501680, Volume 2: Expansion and Crisis. New Haven: Yale University Press.

Rockhill, W.W. 1913. Notes on the relations and trade of China with the eastern archipelago and the coasts of the Indian Ocean during the fourteenth century. T'oung Pao 14(4):473-476.

Rockhill, W.W. 1914. Notes on the relations and trade of China with the eastern archipelago and the coasts of the Indian Ocean during the fourteenth century: part I. T'oung Pao 15(3):419-447.

Rockhill, W.W. 1915a. Notes on the relations and trade of China with the eastern archipelago and the coasts of the Indian Ocean during the fourteenth century: part II. T'oung Pao 16(2):236-271.

Rockhill, W.W. 1915b. Notes on the relations and trade of China with the eastern archipelago and the coasts of the Indian Ocean during the fourteenth century: part II. T'oung Pao 16(4):435-467.

Scott, R.E. 1993. The Porcelains of Jingdezhen. London: School or Oriental and Africa Studies, University of London.

Scott, W.H. 1989. Filipinos in China before 1500. Manila: China Studies Program, De La Salle University.
Singapore National Heritage Board and National Museum (Singapore). 1995. The Legacy of Majapahit. Singapore: National Heritage Board.

So, B.K.L. 1994. The trade ceramics industry of southern Fukien during the Sung Dynasty. Journal of Sung Yuan Studies 24:1-19.

So, B.K.L. 2000. Prosperity, Region, and Institutions in Maritime China: The South Fukien Pattern, 946-1368. Cambridge, MA: Harvard University Asia Center.

Speakman, R.J., M.D. Glascock, R.H. Tykot, C. Descantes, J.J. Thatcher, C.E. Skinner, and K.M. Lienhop. 2007. Selected applications of laser ablation inductively coupled plasmamass spectrometry to archaeological research. In M.D. Glascock, R.J. Speakman, and R.W. Popelka-Filcoff (eds.), Archaeological Chemistry: Analytical Techniques and Archaeological Interpretation, pp. 275-296. Washington, DC: American Chemical Society.

Tenazas, R.C.P., and K.L. Hutterer. 1968. Preliminary report on the salvage excavation project in Cebu City. In $\mathrm{R}$. Rahmann and G.R. Ang (eds.), Dr. H. Otley Beyer, Dean of Philippine Anthropology (A Commemorative Issue). Cebu City, Philippines: The University of San Carlos Divine Word Press.

The Underwater Research Center of the National Museum of China, The Institute of Cultural Relics and Archaeology of Fujian Museum, and Wuyishan Museum (中国国家博 物馆水下考古研究中心，福建博物院文物考古研究所， and 武夷山市博物馆). 2015. Wuyishan Old Kiln Sites (武 夷山古窑址). Beijing (北京): Science Press (科学出版社 ). [In Chinese.]

Wade, G. 2003. The Pre-modern East Asian Maritime Realm: An Overview of European-language Studies. www.ari.nus.edu.sg/docs/wps/wps03_016.pdf.

Wade, G. 2009. An Early Age of Commerce in Southeast Asia, 900-1300 CE. Journal of Southeast Asian Studies 40(2):221-265.

Wheatley, P. 1959. Geographical notes on some commodities involved in Sung maritime trade. Journal of the Malayan Branch of the Royal Asiatic Society 32(2):1-140.

Wong, W.Y. 2010. A Preliminary Study of Some Economic Activities of Khmer Empire: Examining the Relationship between the Khmer and Guangdong Ceramic Industries during the 9th to 14th Centuries Doctoral dissertation, Southeast Asian Studies, National University of Singapore.

Wood, N. 2011. Chinese Glazes: Their Origins, Chemistry, and Recreation. London: A \& C Black.

Wu, C.H. 1959. A study of references to the Philippines in Chinese sources from earliest times to the Ming Dynasty. Philippine Social Sciences and Humanities Review 24:1181.

Yap, C.T. 1987. X-ray fluorescence studies on low-Z elements of Straits Chinese porcelains using Fe-55 and Cd-109 annular sources. X-Ray Spectrometry 16:55-56.

Yap, C.T 1991. EDXRF studies of the Nanking cargo with principal component analysis of trace elements. Applied Spectroscopy 45(4):584-587.

Ye, W. 1994. A preliminary discussion of Fujian wares made in imitation of Zhejiang glazed wares. In C. Ho (ed.), New Light on Chinese Yue and Longquan Wares: Archaeological Ceramics Found in Eastern and Southern 
Asia, A.D. 800-1400, pp. 120-128. Hong Kong: Center of Asian Studies, The University of Hong Kong.

Yu, K.N., and J.M. Miao. 1996. Non-destructive and quantitative investigation of Jingdezhen blue and white porcelains using EDXRF. Journal of X-ray Science and Technology 6:167-171.

Yu, K.N., and J.M. Miao. 1997. Locating the origins of blue and white porcelains using EDXRF. Applied Radiation and Isotopes 48(7):959-963.

Yu, K.N., and J.M. Miao. 1998. Multivariate analysis of the energy dispersive X-ray fluorescence results from blue and white Chinese porcelains. Archaeometry 40(2):331339.

Zhang, H., Z. Zhao, D. Yang, S. Wang, and W. Guo. 2009. Xray emission fluorescence (XRF) analysis of origin of raw materials of light dark reddish brown porcelain and porcelain with black flower on a white background of Dangyangyu kiln. Journal of Radioanalytical and Nuclear Chemistry 279(1):307-312.

Zhao, R. 2012 [1911].Chau Jukua his work on the Chinese and Arab trade in the twelfth, and thirteenth centuries, entitled Chu-Fan-Chï: W.W. Rockhill (ed.). Hong Kong: Forgotten Books.

Zhu, T., H. Huang, H. Wang, L. Hu, and X. Yi. 2011. Comparison of celadon from the Yaozhou and Xicun kilns in the Northern Song Dynasty of China by X-ray fluorescence and microscopy. Journal of Archaeological Science 38:3134-3140.

Zhu, T., W. Sun, H. Zhang, G. Kuang, and L. Lu. 2012. Study on the provenance of Xicun qingbai wares from the Northern Song Dynasty of China. Archaeometry 54(3):475-488.

Zhu, T., C. Wang, H. Wang, and Z. Mao. 2010. The preliminary study on kiln identification of Chinese ancient qingbai wares by ICP-AES. Journal of Cultural Heritage 11:482486. 
APPENDIX 1: Ceramic Sample Information

\begin{tabular}{|c|c|c|c|c|c|c|}
\hline $\begin{array}{l}\text { LA-ICP-MS } \\
\text { Sample ID }\end{array}$ & $\begin{array}{l}\text { Material } \\
\text { Analyzed }\end{array}$ & Glaze Color & Paste Texture & Paste Color & Object Description & Form \\
\hline JSW106 & Glaze & Bluish-white & Fine & Sugary white & Qingbai-style box & Box lid \\
\hline JSW107 & Glaze & Bluish-white & Fine & Sugary white & Qingbai-style box & Box lid \\
\hline JSW108 & Glaze & Bluish-white & Fine & Sugary white & Qingbai-style box & Box base \\
\hline JSW109 & Glaze & Bluish-white & Fine & Sugary white & Qingbai-style box & Box lid \\
\hline JSW110 & Glaze & Bluish-white & Fine & Sugary white & Qingbai-style box & Box base \\
\hline JSW111 & Glaze & Bluish-white & Fine & Sugary white & Qingbai-style box & Box base \\
\hline JSW112 & Glaze & Bluish-white & Fine & Sugary white & Qingbai-style box & Box base \\
\hline JSW113 & Glaze & Bluish-white & Fine & Sugary white & Qingbai-style box & Box base \\
\hline JSW114 & Glaze & Bluish-white & Fine & Sugary white & Qingbai-style box & Box base \\
\hline JSW116 & Glaze & Bluish-white & Fine & Sugary white & Qingbai-style box & Box base \\
\hline JSW117 & Glaze & Bluish-white & Fine & Sugary white & Qingbai-style box & Box base \\
\hline JSW121 & Paste & $\begin{array}{l}\text { Black slip (some green } \\
\text { glaze) }\end{array}$ & Fine-medium & $?$ & Painted ware box & Box base \\
\hline JSW122 & Paste & Milky white & Fine & Sugary white & Qingbai-style box & Box base \\
\hline JSW123 & Paste & Bluish-white & Fine & Sugary white & Qingbai-style box & Box base \\
\hline JSW124 & Paste & Bluish-white & Fine & Sugary white & Qingbai-style box & Box lid \\
\hline JSW125 & Paste & Light blue & Fine & Sugary white & $\begin{array}{l}\text { Qingbai-style (white } \\
\text { ware?) vase }\end{array}$ & Vase \\
\hline JSW126 & Paste & Light blue-aqua & Fine-medium & $\begin{array}{l}\text { Cream with dark inclu- } \\
\text { sions }\end{array}$ & Qingbai ewer & Ewer \\
\hline JSW127 & Paste & Light blue-aqua & Fine-medium & $\begin{array}{l}\text { Cream with dark inclu- } \\
\text { sions }\end{array}$ & Qingbai ewer & Ewer \\
\hline JSW129 & Paste & $\begin{array}{l}\text { Black slip with green over- } \\
\text { glaze }\end{array}$ & Fine-medium & Purplish-gray & Painted ware ewer & Ewer \\
\hline JSW131 & Paste & Light blue-aqua & Fine-medium & $\begin{array}{l}\text { Cream with dark inclu- } \\
\text { sions }\end{array}$ & Qingbai plate & Saucer \\
\hline JSW133 & Paste & Aqua & Fine & $\begin{array}{l}\text { Cream with dark inclu- } \\
\text { sions }\end{array}$ & Qingbai plate & $\begin{array}{l}\text { Shallow dish, } \\
\text { saucer, or } \\
\text { plate base }\end{array}$ \\
\hline JSW134 & Paste & $\begin{array}{l}\text { Light blue (some greenish } \\
\text { tint) to aqua when pooling }\end{array}$ & Fine-medium & Sugary white & $\begin{array}{l}\text { Qingbai-style (white } \\
\text { ware) vase }\end{array}$ & Vase \\
\hline JSW135 & Paste & Light greenish-gray & Fine & Light gray & Green-glazed bowl & Bowl \\
\hline JSW136 & Paste & Aqua & Fine-medium & $\begin{array}{l}\text { Cream with dark inclu- } \\
\text { sions }\end{array}$ & Qingbai plate & Saucer? \\
\hline JSW137 & Paste & Light blue-aqua & Fine-medium & $\begin{array}{l}\text { Cream with dark inclu- } \\
\text { sions }\end{array}$ & Qingbai plate & Saucer \\
\hline JSW138 & Paste & Aqua & Fine & Cream & Qingbai plate & Shallow dish? \\
\hline JSW139 & Paste & Aqua & Fine-medium & $\begin{array}{l}\text { Cream with dark inclu- } \\
\text { sions }\end{array}$ & Qingbai ewer & Ewer \\
\hline JSW151 & Paste & Aqua & Fine & White & Qingbai plate & Shallow dish? \\
\hline JSW152 & Paste & Light blue-aqua & Fine-medium & $\begin{array}{l}\text { Cream with dark inclu- } \\
\text { sions }\end{array}$ & Qingbai plate & $\begin{array}{l}\text { Saucer or } \\
\text { plate base }\end{array}$ \\
\hline JSW153 & Paste & Aqua & Fine & White & Qingbai plate & Shallow dish? \\
\hline JSW154 & Paste & Light blue & Fine-medium & $\begin{array}{l}\text { Cream with dark inclu- } \\
\text { sions }\end{array}$ & Green-glazed bowl & Bowl \\
\hline JSW156 & Paste & $\begin{array}{l}\text { Light blue-aqua (translu- } \\
\text { cent) }\end{array}$ & Fine & Sugary white & Qingbai plate & Shallow dish \\
\hline JSW157 & Paste & $\begin{array}{l}\text { Light blue-aqua (translu- } \\
\text { cent) }\end{array}$ & Fine & Sugary white & Qingbai plate & Shallow dish \\
\hline JSW158 & Paste & $\begin{array}{l}\text { Weathered green glaze } \\
\text { over black slip }\end{array}$ & Fine-medium & Dirty cream & Painted ware ewer & Ewer \\
\hline JSW159 & Paste & $\begin{array}{l}\text { Weathered green glaze } \\
\text { over black slip }\end{array}$ & Fine-medium & Sugary white & Painted ware bowl & Bowl \\
\hline JSW160 & Paste & $\begin{array}{l}\text { Weathered green glaze } \\
\text { over black slip }\end{array}$ & Fine-medium & Bright white & Painted ware jar & Jar \\
\hline JSW161 & Paste & $\begin{array}{l}\text { Light blue-aqua (translu- } \\
\text { cent) }\end{array}$ & Fine & Sugary white & Qingbai bowl & Bowl \\
\hline
\end{tabular}




\begin{tabular}{|c|c|c|c|c|c|c|}
\hline $\begin{array}{l}\text { LA-ICP-MS } \\
\text { Sample ID }\end{array}$ & $\begin{array}{l}\text { Material } \\
\text { Analyzed }\end{array}$ & Glaze Color & Paste Texture & Paste Color & Object Description & Form \\
\hline JSW163 & Paste & $\begin{array}{l}\text { Light blue-aqua (translu- } \\
\text { cent) }\end{array}$ & Fine & Sugary grayish-white & Qingbai bowl & Bowl \\
\hline JSW164 & Paste & $\begin{array}{l}\text { Weathered green glaze } \\
\text { over black slip }\end{array}$ & Fine-medium & Dirty cream & Painted ware ewer & Ewer \\
\hline JSW165 & Paste & $\begin{array}{l}\text { Weathered green glaze } \\
\text { over black slip }\end{array}$ & Fine-medium & White? & Painted ware bowl & Bowl \\
\hline JSW168 & Paste & $\begin{array}{l}\text { Light blue-aqua (translu- } \\
\text { cent) }\end{array}$ & Fine & Sugary white & Qingbai plate & Shallow dish \\
\hline JSW169 & Paste & $\begin{array}{l}\text { Weathered green glaze } \\
\text { over black slip }\end{array}$ & Fine-medium & Gray & Painted ware ewer & Ewer \\
\hline JSW170 & Paste & Weathered green glaze & Fine-medium & Purplish-gray & Painted ware ewer & Ewer \\
\hline JSW171 & Paste & $\begin{array}{l}\text { Weathered green glaze } \\
\text { over black slip }\end{array}$ & Fine-medium & Sugary white & Painted ware ewer & Ewer \\
\hline JSW173 & Paste & $\begin{array}{l}\text { Weathered green glaze } \\
\text { over black slip }\end{array}$ & Fine-medium & Sugary white & Painted ware bowl & Bowl \\
\hline JSW174 & Paste & $\begin{array}{l}\text { Weathered green glaze } \\
\text { over black and white slip }\end{array}$ & Fine-medium & Gray & Painted ware ewer & Ewer \\
\hline JSW176 & Glaze & Light blue-aqua & Fine-medium & $\begin{array}{l}\text { Cream with dark inclu- } \\
\text { sions }\end{array}$ & Qingbai ewer & Ewer \\
\hline JSW178 & Glaze & Aqua & Fine & Bright white & Qingbai plate & Shallow dish? \\
\hline JSW180 & Glaze & Aqua & Fine-medium & $\begin{array}{l}\text { Cream with dark inclu- } \\
\text { sions }\end{array}$ & Qingbai plate & Saucer \\
\hline JSW183 & Glaze & Light blue-aqua & Fine-medium & $\begin{array}{l}\text { Cream with dark inclu- } \\
\text { sions }\end{array}$ & Qingbai ewer & Ewer \\
\hline JSW184 & Glaze & Aqua & Fine-medium & $\begin{array}{l}\text { Cream with dark inclu- } \\
\text { sions }\end{array}$ & Qingbai ewer & Ewer \\
\hline JSW185 & Glaze & $\begin{array}{l}\text { Light blue-aqua (translu- } \\
\text { cent) }\end{array}$ & Fine & Sugary white & Qingbai plate & Shallow dish \\
\hline JSW186 & Glaze & Aqua & Fine & White & Qingbai plate & Shallow dish? \\
\hline JSW188 & Paste & Light blue & Fine & Sugary white & $\begin{array}{l}\text { Qingbai-style (white } \\
\text { ware) vase }\end{array}$ & Vase \\
\hline JSW189 & Paste & Light blue-aqua & Fine-medium & $\begin{array}{l}\text { Cream with dark inclu- } \\
\text { sions }\end{array}$ & Qingbai plate & Saucer \\
\hline JSW190 & Paste & Light blue-aqua & Fine-medium & $\begin{array}{l}\text { Cream with dark inclu- } \\
\text { sions }\end{array}$ & Qingbai plate & $\begin{array}{l}\text { Saucer or } \\
\text { plate base }\end{array}$ \\
\hline JSW191 & Paste & Aqua & Fine & Bright white & Qingbai plate & Shallow dish? \\
\hline JSW192 & Paste & Qingbai & Fine-medium & $?$ & Qingbai plate & Shallow dish \\
\hline JSW193 & Paste & Light blue-aqua & Fine-medium & $\begin{array}{l}\text { Cream with dark inclu- } \\
\text { sions }\end{array}$ & Qingbai vase & Vase \\
\hline JSW194 & Paste & Aqua & Fine-medium & $\begin{array}{l}\text { Cream with dark inclu- } \\
\text { sions }\end{array}$ & Qingbai plate & Saucer \\
\hline JSW195 & Paste & Light blue-aqua & Fine-medium & $\begin{array}{l}\text { Cream with dark inclu- } \\
\text { sions }\end{array}$ & Qingbai ewer & Ewer \\
\hline JSW196 & Paste & Light greenish-gray & Fine-medium & White with dark inclusions & Green-glazed bowl & Bowl \\
\hline JSW197 & Paste & $\begin{array}{l}\text { Black slip with green over- } \\
\text { glaze }\end{array}$ & Fine-medium & Pale gray & $\begin{array}{l}\text { Painted ware ewer or } \\
\text { vase }\end{array}$ & Ewer or vase \\
\hline JSW198 & Paste & Light greenish gray & Fine & Sugary white & Green-glazed bowl & Bowl \\
\hline JSW199 & Paste & Light-medium olive-green & Fine & Lavender gray & Green-glazed bowl & Bowl \\
\hline JSW200 & Paste & Light olive-green & Fine & Lavender gray & Green-glazed bowl & Bowl \\
\hline JSW201 & Paste & Qingbai weathered to tan & & Cream with thin gray core & Qingbai bowl & Bowl \\
\hline JSW202 & Paste & Light grayish-green & Fine & Sugary white & Green-glazed bowl & Bowl \\
\hline JSW203 & Paste & Light greenish gray & Fine & Sugary white & Green-glazed bowl & Bowl \\
\hline JSW204 & Paste & Light greenish gray & Fine & Sugary white & Green-glazed bowl & Bowl \\
\hline JSW205 & Paste & Light olive-green & Fine & Lavender gray & Green-glazed bowl & Bowl \\
\hline JSW206 & Paste & Light-medium olive-green & Fine & Lavender gray & Green-glazed bowl & Bowl \\
\hline
\end{tabular}




\begin{tabular}{|c|c|c|c|c|c|c|}
\hline $\begin{array}{l}\text { LA-ICP-MS } \\
\text { Sample ID }\end{array}$ & $\begin{array}{l}\text { Material } \\
\text { Analyzed }\end{array}$ & Glaze Color & Paste Texture & Paste Color & Object Description & Form \\
\hline JSW207 & Paste & Light blue-aqua & Fine & Sugary white & Qingbai-style bowl & Bowl \\
\hline JSW208 & Paste & $\begin{array}{l}\text { Light-medium bluish-olive- } \\
\text { green }\end{array}$ & Fine & Lavender gray & Green-glazed bowl & Bowl \\
\hline JSW209 & Glaze & Light blue & Fine & Sugary white & $\begin{array}{l}\text { Qingbai-style (white } \\
\text { ware) vase }\end{array}$ & Vase \\
\hline JSW211 & Glaze & $\begin{array}{l}\text { Light-medium bluish-olive- } \\
\text { green }\end{array}$ & Fine & Lavender gray & Green-glazed bowl & Bowl \\
\hline JSW212 & Glaze & Light blue-aqua & Fine & Sugary white & Qingbai-style bowl & Bowl \\
\hline JSW213 & Glaze & Light blue-aqua & Fine-medium & $\begin{array}{l}\text { Cream with dark inclu- } \\
\text { sions }\end{array}$ & Qingbai plate & $\begin{array}{l}\text { Saucer or } \\
\text { plate base }\end{array}$ \\
\hline JSW214 & Glaze & Light blue-aqua & Fine-medium & $\begin{array}{l}\text { Cream with dark inclu- } \\
\text { sions }\end{array}$ & Qingbai vase & Vase \\
\hline JSW219 & Glaze & Light greenish gray & Fine & Sugary white & Green-glazed bowl & Bowl \\
\hline JSW220 & Glaze & Light greenish gray & Fine & Sugary white & Green-glazed bowl & Bowl \\
\hline JSW900 & Paste & Aqua & Fine-medium & $\begin{array}{l}\text { Cream with dark inclu- } \\
\text { sions }\end{array}$ & Qingbai plate & Saucer \\
\hline JSW901 & Paste & $\begin{array}{l}\text { Black slip with green over- } \\
\text { glaze }\end{array}$ & Fine-medium & Grayish lavender & Painted ware vase & Vase \\
\hline JSW902 & Paste & Aqua & Fine-medium & Cream & Qingbai ewer & Ewer \\
\hline JSW904 & Paste & $\begin{array}{l}\text { Weathered green glaze } \\
\text { over black slip }\end{array}$ & Fine-medium & Gray & Painted ware ewer & Ewer \\
\hline JSW905 & Glaze & Bluish-white & Fine & Sugary white & Qingbai-style box & Box lid \\
\hline JSW906 & Glaze & Bluish-white & Fine & Sugary white & Qingbai-style box & Box lid \\
\hline JSW907 & Glaze & Bluish-white & Fine & Sugary white & Qingbai-style box & Box lid \\
\hline JSW908 & Glaze & Light blue-aqua & Fine-medium & $\begin{array}{l}\text { Cream with dark inclu- } \\
\text { sions }\end{array}$ & Qingbai plate & Saucer \\
\hline JSW909 & Glaze & Light blue-aqua & Fine-medium & $\begin{array}{l}\text { Cream with dark inclu- } \\
\text { sions }\end{array}$ & Qingbai plate & $\begin{array}{l}\text { Saucer or } \\
\text { plate base }\end{array}$ \\
\hline JSW910 & Glaze & Light blue-aqua & Fine-medium & $\begin{array}{l}\text { Cream with dark inclu- } \\
\text { sions }\end{array}$ & Qingbai plate & Shallow dish \\
\hline
\end{tabular}

